\title{
Selective depletion of tumour suppressors Deleted in Colorectal Cancer (DCC) and neogenin by environmental and endogenous serine proteases: linking diet and cancer
}

Caroline M. Forrest ${ }^{1 \dagger}$, Kara McNair $^{1+}{ }^{1+}$ Maria C. J. Vincenten ${ }^{1+}$, L. Gail Darlington ${ }^{2}$ and Trevor W. Stone ${ }^{1 *}$

\begin{abstract}
Background: The related tumour suppressor proteins Deleted in Colorectal Cancer (DCC) and neogenin are absent or weakly expressed in many cancers, whereas their insertion into cells suppresses oncogenic behaviour. Serine proteases influence the initiation and progression of cancers although the mechanisms are unknown.

Methods: The effects of environmental (bacterial subtilisin) and endogenous mammalian (chymotrypsin) serine proteases were examined on protein expression in fresh, normal tissue and human neuroblastoma and mammary adenocarcinoma lines. Cell proliferation and migration assays (chemoattraction and wound closure) were used to examine cell function. Cells lacking DCC were transfected with an ectopic dcc plasmid.

Results: Subtilisin and chymotrypsin selectively depleted DCC and neogenin from cells at nanomolar concentrations without affecting related proteins. Cells showed reduced adherence and increased migration, but after washing they re-attached within $24 \mathrm{~h}$, with recovery of protein expression. These effects are induced by chymotryptic activity as they are prevented by chymostatin and the soybean Bowman-Birk inhibitor typical of many plant protease inhibitors.

Conclusions: Bacillus subtilis, which secretes subtilisin is widely present in soil, the environment and the intestinal contents, while subtilisin itself is used in meat processing, animal feed probiotics and many household cleaning agents. With chymotrypsin present in chyme, blood and tissues, these proteases may contribute to cancer development by depleting DCC and neogenin. Blocking their activity by Bowman-Birk inhibitors may explain the protective effects of a plant diet. Our findings identify a potential non-genetic contribution to cancer cell behaviour which may explain both the association of processed meats and other factors with cancer incidence and the protection afforded by plant-rich diets, with significant implications for cancer prevention.
\end{abstract}

Keywords: Deleted in colorectal cancer, DCC, Neogenin, Serine proteases, Chymotrypsin, Subtilisin

\footnotetext{
*Correspondence: Trevor.Stone@glasgow.ac.uk;

trevorwstone@btinternet.com

${ }^{\dagger}$ Equal contributors

${ }^{1}$ College of Medical, Veterinary and Life Sciences, West Medical Building,

University of Glasgow, Glasgow G12 8QQ, UK

Full list of author information is available at the end of the article
} 


\section{Background}

Expression of the tumour suppressor proteins Deleted in Colorectal Cancer (DCC) or the structurally related protein neogenin is reduced in many cancers, the extent of loss compared with control tissue correlating with degree of metastasis and with poor patient prognosis [1-8]. Although early work on DCC revealed genetic abnormalities such as frequent Loss of Heterozygosity, outright mutations have been encountered less frequently than expected, leading to suggestions that functional abnormalities of the protein may often be non-genetic in origin [9, 10]. Experimental inhibition of DCC can increase proliferation or migration in different cell types [11-14] while, conversely, insertion of the $d c c$ gene into cells inhibits proliferation, invasion and metastatic potential [13-17].

Similarly, low levels of the structurally related protein neogenin have been linked with an increased propensity to develop cancer [18-22], while over-expression induces apoptosis [22, 23]. Reduced neogenin expression has a particularly prominent association with cancers in the CNS and mammary tissues [21, 24-26].

Both DCC and neogenin are involved in defining the balance between cell survival or death and between differentiation and de-differentiation towards an un-regulated, hyper-proliferative and potentially oncogenic phenotype [27-29]. They are receptors for the ligand netrin, an extracellular, secreted protein. In the absence of netrin, DCC or neogenin activate cell death programmes including apoptosis, leading to the concept that they are "dependence receptors", regulating cell viability depending on the ambient concentration of netrin [30-33]. If cells escape from their home tissue by damage, inflammation or natural turnover, the reduced netrin concentration unleashes dependence receptor-induced cell death, preventing uncontrolled proliferation in distant tissues. If DCC or neogenin are absent, however, this mechanism cannot operate and proliferation or migration will proceed unchecked [34].

Serine proteases are present in relatively high concentrations in many cancers and can influence cell proliferation and migration [27, 28, 35-41] while serine protease inhibitors can suppress tumour invasion and metastasis [42-45]. Specific sites and mechanisms of action, however, remain unclear.

We now report a major link between these two groups of compounds, showing that nanomolar concentrations of the serine protease subtilisin, a chymotryptic protease secreted by the common environmental bacterium Bacillus subtilis and related organisms, and mammalian chymotrypsin itself, deplete the levels of DCC and neogenin in cells. Expression of a third dependence receptor targeted by netrin, unco-ordinated-5C [46], is also affected but to a lesser degree than DCC or neogenin.
B. subtilis is present in soil, while subtilisin itself is used to increase tenderness and flavour in some processed meat products and is present in many cleaning materials. Since orally acquired live bacteria and spores of $B$. subtilis can survive in the intestine of humans and other mammals [47], and the concentrations of chymotrypsin in tissues and intestinal chyme are similar to those studied here, their ability to remove DCC and neogenin could represent a significant factor in the effects of diet and environment on cancer susceptibility.

We also show that Bowman-Birk inhibitors present in many food crops including fruit, vegetables and cereals [48-51] can block these effects of serine proteases, providing a potential explanation of the protective effects of a plant-rich diet. The removal or reduction of subtilisin in the human food chain and cleaning products, and a plant-based diet rich in Bowman-Birk inhibitors, might substantially reduce the worldwide incidence of several forms of cancer.

\section{Methods \\ Tissue slices}

Initial experiments were performed using sections of adult rat hippocampus which can be maintained for several hours without the need for serum or other additives. These slices are exactly similar to those used routinely for the electrophysiological recording of synaptic potentials [52, 53]. Briefly, male Wistar rats (100-150 g from Harlan Olac, UK) were killed using urethane $(5 \mathrm{ml} / \mathrm{kg})$ and cervical dislocation. The brain was removed into icecold artificial cerebrospinal fluid (aCSF) of composition (in $\mathrm{mM}$ ): $\mathrm{NaCl} 115 ; \mathrm{KH}_{2} \mathrm{PO}_{4} 2.2 ; \mathrm{KCl} 2 ; \mathrm{MgSO}_{4}$ 1.2; $\mathrm{NaHCO}_{3} 25 ; \mathrm{CaCl}_{2}$ 2.5; glucose 10 , gassed with $5 \% \mathrm{CO}_{2}$ in air. The hippocampi were chopped into $450 \mu \mathrm{m}$ transverse slices and allowed to recover for 1-2 $\mathrm{h}$, when compounds were added for $4 \mathrm{~h}$.

\section{Immunoblotting}

Western blots were generated as described previously $[52,54,55]$. Briefly, tissue slices were homogenised in RIPA buffer with a Roche complete protease inhibitor tablet and centrifuged $\left(18000 \mathrm{~g}, 5 \mathrm{~min}, 4^{\circ} \mathrm{C}\right)$. Supernatant protein concentration was determined using the Bio-Rad assay (Bio-Rad, Hemel Hempstead, UK) and normalised to $10 \mu \mathrm{g}$. The protein samples were subsequently loaded onto NuPAGE Novex 4-12 \% Bis-Tris (1.0 mm) gels and run at 175 volts for $70 \mathrm{~min}$. The separated proteins were blotted onto Invitrolon polyvinylidene difluoride membranes (35 V, $75 \mathrm{~min}$ ) after which membranes were rinsed, blocked for $1 \mathrm{~h}$ in a milk solution in Tris-buffered saline containing $0.05 \%$ Tween (TBST), followed by overnight incubation at $4{ }^{\circ} \mathrm{C}$ with primary antibody. After further washing and treatment with horseradish peroxidase (HRP) conjugated secondary antibody, blots were washed 
3 times and visualised using a Pierce Enhanced Chemiluminescence 2 detection kit.

Western blot analysis was carried out using the following primary antibodies:-

From Santa Cruz, Insight Biotechnology, Wembley, UK:Neogenin (goat polyclonal, sc-6536, 1:1000 dilution); Unc5A (goat polyclonal, sc-67902, 1:1000 dilution); Unc5C (goat polyclonal, sc-54442 1:500 dilution); Shh (goat polyclonal, sc-1194, 1:1000 dilution); RhoA (mouse monoclonal, sc-418, 1:5000 dilution); From BD Pharmingen, Oxford, UK):- DCC (mouse monoclonal, 554223, 1:5000 dilution).

RhoA was included in all experiments as the standard loading and transfer control since in motile and invasive cells the classical controls such as actin and tubulin, associated with the cytoskeletal involvement in movement, are inappropriate [56, 57].

Secondary HRP-conjugated antibodies were used at a 1:5000 dilution: donkey anti-goat HRP (sc-2020), goat anti-mouse (sc-2005), and donkey anti-rabbit HRP (sc2313) (Santa Cruz, Insight Biotechnology, Wembley, UK). The blots were quantified using Image J $[54,55,58]$.

\section{Immunocytochemistry}

Cells were passaged into 24-well plates containing poly D-lysine $(50 \mu \mathrm{g} / \mathrm{ml})$ coated glass coverslips and after experimental observation were fixed with $4 \%$ paraformaldehyde (PFA), rinsed and incubated overnight in primary antibody. After further rinsing with PBS, cells were incubated in the appropriate secondary fluorescent antibody at 1:200 dilution in PBS with $0.3 \%$ Triton X (1 h) followed by rinsing and mounting the coverslips with Vectashield ${ }^{\circ}$ fluorescent mounting medium.

Primary antibodies used were: DCC 1:500 (BD Pharmingen, Oxford, UK, \#554223); doublecortin (DCX) 1:200 (Santa Cruz, California; \#SC8066), neogenin 1:500 (Santa Cruz, California; \#SC6536).

Secondary antibodies (all 1:200) were AlexaFluor 594 goat anti-mouse \#A11032; AlexaFluor 488 goat anti-rabbit \#A11008; AlexaFluor rabbit anti-goat \#A11078 (Life Technologies, Paisley, UK).

\section{Cell cultures}

All cells were maintained using the procedures and media recommended by the supplier ECACC (Wiltshire, UK). The SH-SY5Y cell line, \#94030304) is an adherent, human neuroblastoma cell line obtained at a passage number of 17. This cell line was only used up to passage 30 as beyond this the cells lose their neuronal characteristics. Cells were plated at an initial density of $5 \times 10^{4}$ cells $/ \mathrm{ml}$ unless otherwise stated. This cell line was passaged once per week and fed every 2-3 days with a $50 \%$ media change.
The MDA-MB-231 cell line is an adherent, human Caucasian breast adenocarcinoma cell line purchased at passage 40 (ECACC \#92020424) and used for no more than 30 further passages. Cells were plated at an initial density of $1 \times 10^{5}$ cells $/ \mathrm{ml}$ unless otherwise stated and were passaged twice per week and fed every 2-3 days, when required, with a $50 \%$ media change.

The MCF-7 cell line is an adherent, human Caucasian breast adenocarcinoma cell line purchased at passage 15 (ECACC \#86012803) and used for no more than 30 passages following resuscitation. Cells were plated at an initial density of $1 \times 10^{5}$ cells $/ \mathrm{ml}$ unless otherwise stated. These cells were passaged once per week and fed every $2-3$ days with a $50 \%$ medium change.

Human Caucasian colon adenocarcinoma ( $\mathrm{CaCo}-2)$ cells (ECACC \#86010202) were purchased at passage number 45 and were used for up to 20 passages. Cells were plated at an initial density of $1 \times 10^{5}$ cells $/ \mathrm{ml}$ unless otherwise stated and were passaged once per week and fed every 2-3 days with a $50 \%$ media change.

\section{Replating and recovery}

MDA-MB-231 cells were plated at a density of $3 \times 10^{5}$ cells $/ \mathrm{ml}$ in 6-well plates and were allowed to attach to the plates for $24 \mathrm{~h}$ before the addition of subtilisin $(1 \mu \mathrm{M})$. After $24 \mathrm{~h}$, detached cells were collected, washed and replated in fresh medium, then left for $24 \mathrm{~h}$ before harvesting for Western blotting. Cells were photographed at x20 magnification on an Olympus IX50 inverted microscope attached to an Olympus DP50 camera.

\section{Agarose spot migration}

Based on a published method [59], low melting point agarose was prepared and human netrin-4 (R \& D systems, \#1254-N4) was added to $1000 \mathrm{ng} / \mathrm{ml}$. A spot of $10 \mu \mathrm{l}$ of LMA solution was pipetted into the centre of each well and allowed to set for at least $1 \mathrm{~h}$ at $4{ }^{\circ} \mathrm{C}$. Cells were passaged and transferred to the spot-containing wells for $4 \mathrm{~h}$ at $37^{\circ} \mathrm{C}$, when the medium was changed to contain $0.1 \%$ serum. After $24 \mathrm{~h}$, six photographs were taken of each well at $\mathrm{x} 4$ magnification, with a minimum of 4 different experiments from 4 different passages. Image J (http://rsb.info.nih.gov/ij/) was used to analyse cell distribution in the photographs and the average number of cells per spot was calculated for each experiment.

\section{Wound healing assay}

Cells were plated at a density of $2 \times 10^{5}$ cells $/ \mathrm{ml}$ in 6 -well plates which had been marked with a reference grid. A confluent monolayer formed in approximately 3 days, when a scratch wound was made down the centre of each well $[60,61]$. The cells were then washed and placed in normal (10\% serum) medium. Photographs ( $\mathrm{x} 4$ magnification) were taken immediately $(0 \mathrm{~h})$ and at 
$72 \mathrm{~h}$ at 3 points along the wound using an Olympus DP50 camera attached to an Olympus IX50 inverted microscope. The score grid ensured that the same area of cells was captured in each photograph. Experimental treatments were started after the initial photograph, and wound closure was quantified by measuring open wound area, using T-scratch software [62]. When subtilisin was added, photographs were also taken at $24 \mathrm{~h}$ and $48 \mathrm{~h}$.

\section{Morphology of SH-SY5Y cells}

To examine morphological changes in SH-SY5Y cells, passaged cells were grown in medium containing $1 \%$ FCS for 3 days to induce neurite formation. Chymotrypsin $(100 \mathrm{nM})$ was added on days 1 and 3. On day 6, cells were rinsed, fixed with $4 \%$ paraformaldehyde and dehydrated followed by staining with filtered Cresyl Violet for $10 \mathrm{~min}$. From three experiments 300 cells were examined, using 50 control cells and 50 treated cells from each group. Cells were photographed (x20) and the images were subsequently analysed using Image $\mathrm{J}$ [63] to determine the number and length of neurites per cell, the number of neurite branch points and the soma diameter.

\section{Proliferation (bromodeoxyuridine BrdU assay)}

Proliferation was assessed in the MCF-7 cells using a colorimetric BrdU ELISA kit (ab126556, Abcam, Cambridge, UK). Each assay was performed in triplicate. MCF-7 cells were plated at $2 \times 10^{5}$ cells $/ \mathrm{ml}$ in 96 -well plates and left to attach for $24 \mathrm{~h}$ before treatment with subtilisin (30, 100 and $300 \mathrm{nM}$ ) or $\alpha$-chymotrypsin (300 and $1000 \mathrm{nM}$ ) for $24 \mathrm{~h}$. BrdU reagent was added for the final 2, 6 and $24 \mathrm{~h}$ of incubation after which the cells were fixed and the DNA denatured. Briefly, cells were washed, incubated with detector antibody $(1 \mathrm{~h})$, washed again and incubated with peroxidase conjugated secondary antibody $(1 \mathrm{~h})$. After washing, cells were incubated with TMB peroxidase substrate and a stop solution was added before reading in a microplate reader (using a dual wavelength of $450 / 550 \mathrm{~nm}$ ). Proliferation was expressed as the mean optical density of BrdU positively labelled cells/BrdU negative cells.

\section{Transfection of DCC plasmid}

A pCMV DCC plasmid (\#16459) was obtained from Addgene courtesy of Dr. B. Vogelstein. This plasmid contains the Cytomegalovirus (CMV) promoter, a strong constitutive promoter, the DCC gene flanked by 2 XhoI restriction sites, polyadenylation signal (Poly A), Ampicillin resistance gene and Neomycin resistance gene. DH5alpha E.coli cells containing the plasmid were grown on agar plates containing $75 \mu \mathrm{g} / \mathrm{ml}$ ampicillin. Individual colonies were inoculated into Luria-Bertani medium containing ampicillin and grown overnight. The remaining bacterial medium was used to extract PCMV DCC plasmid DNA using Pure yield plasmid miniprep system (A1223, Promega UK) following manufacturer's instructions. Transfection was performed in SH-SY5Y and MCF-7 cells passaged $24 \mathrm{~h}$ prior to transfection. To promote the efficiency of transfection, cells were plated at a density sufficient to result in approximately 60-70\% confluency $24 \mathrm{~h}$ after passage. At this time, the medium was removed from each well and replaced with antibiotic free medium for approximately $1 \mathrm{~h}$. The transfection reagent Lipofectamine 2000 was used for successful transfection of the DCC plasmid according to the manufacturer's instructions using a ratio of 1:1 DNA: Lipofectamine 2000. Briefly, DNA (1000 ng) was combined with Lipofectamine 2000 in the presence of Optimem and then incubated at room temperature for $15 \mathrm{~min}$ before adding to cells in antibiotic-free medium. Approximately 4-5 $\mathrm{h}$ after the introduction of DNA, medium was removed and replaced with medium containing antibiotics and test agents as required. Cells were either harvested for Western blot analysis or used for further experiments $48 \mathrm{~h}$ after the initial introduction of the DCC plasmid.

\section{Data analysis and statistics}

Comparisons between two experimental samples were made using a two-tailed Student's $t$ test. Statistical comparisons were made between groups of samples using ANOVA followed by the Dunnet post hoc test to compare several datasets with a common control or the Bonferroni post hoc multiple comparison test for selected datasets, using Instat 3.0 software. A probability value of 0.05 was adopted as the criterion for significance.

\section{Results}

In addition to DCC and neogenin several proteins have been examined in this study that are functionally related to them but which are structurally dissimilar. This comparison allowed assessment of the selectivity of the proteases on proteins and pathways which interact with DCC or neogenin. These proteins include unco-ordinated5C (Unc-5C), another dependence receptor for netrin which can complex with DCC and which is absent from a variety of cancers [64-67]; Unc-5A: to assess the selectivity of serine proteases for unc5 family members; the small GTPase enzyme RhoA $[68,69]$; Sonic hedgehog (Shh), a secreted protein involved in embryonic morphogenesis, cell location and polarisation [70,71] and which modulates the expression of neogenin and netrin [72].

An inverse, concentration-related effect of bacterial subtilisin was observed on the expression of both DCC and neogenin in tissue slices (Fig. 1a,b). A weaker effect was noted on the other netrin receptor unc-5C (Fig. 1c) but no change was seen in the expression of Unc-5A (Fig. 1d), sonic hedgehog (Shh, Fig. 1e) or RhoA (Fig. 1f). To confirm that these effects of subtilisin were mediated 


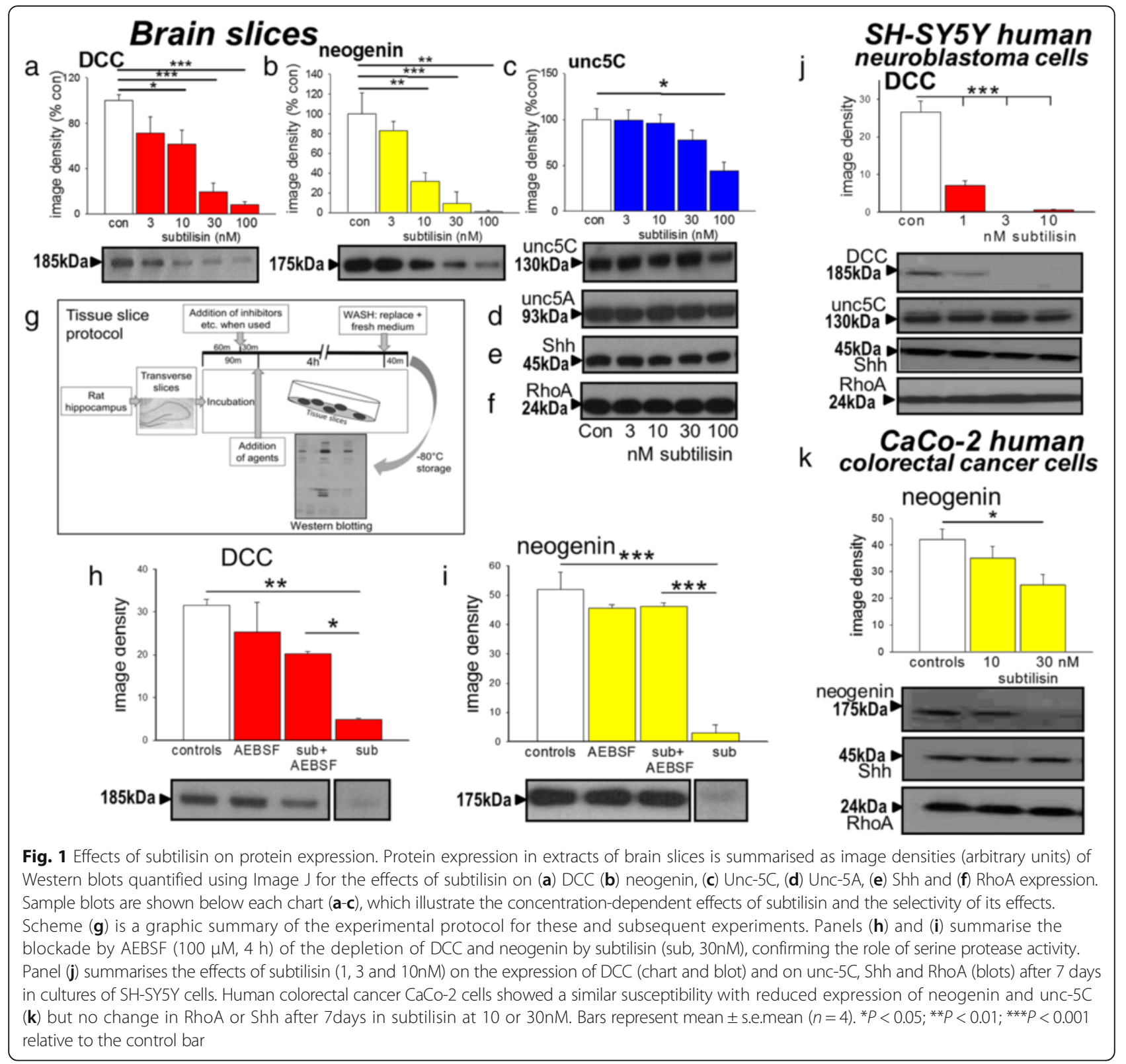

by serine protease activity it was shown, using the protocol in Fig. $1 \mathrm{~g}$, that they were prevented by treatment with the general serine protease inhibitor 4-(2-Aminoethyl) benzene-sulfonyl fluoride hydrochloride (AEBSF) (Fig. 1h, i).

The loss of dependence receptor proteins was confirmed using cell cultures which lack the tissue barriers and non-selective binding sites that exist in intact tissue. When added to SH-SY5Y cultures for 7 days, subtilisin induced a significant loss of DCC expression at concentrations of only $1 \mathrm{nM}$ (Fig. 1j). The selectivity of action was retained and no changes were seen in unc-5C, Shh or RhoA (Fig. 1j).

The ability of subtilisin to deplete neogenin or DCC is not confined to neural tissues. Human $\mathrm{CaCo}-2$ colorectal cancer cells do not express DCC but levels of both neogenin and unc-5C were reduced by subtilisin at 30nM (Fig. 1k) with no effect on RhoA or Shh (Fig. 1k).

Consistent with the classification of subtilisin as a chymotryptic serine protease, chymotrypsin itself also depleted neogenin and DCC in brain tissue (Fig. 2a, b) with a weaker effect on unc-5C (Fig. 2c) and no effect on Unc-5A (Fig. 2d), Shh (Fig. 2e) or RhoA (Fig. 2f). On SH-SY5Y neuroblastoma cells, chymotrypsin produced a similarly selective loss of DCC expression at concentrations similar to those active in intact adult tissue, with approximately $50 \%$ loss of DCC at $300 \mathrm{nM}$. The chymotrypsin-like enzyme cathepsin G, secreted by neutrophils and mast cells as part of the inflammatory 


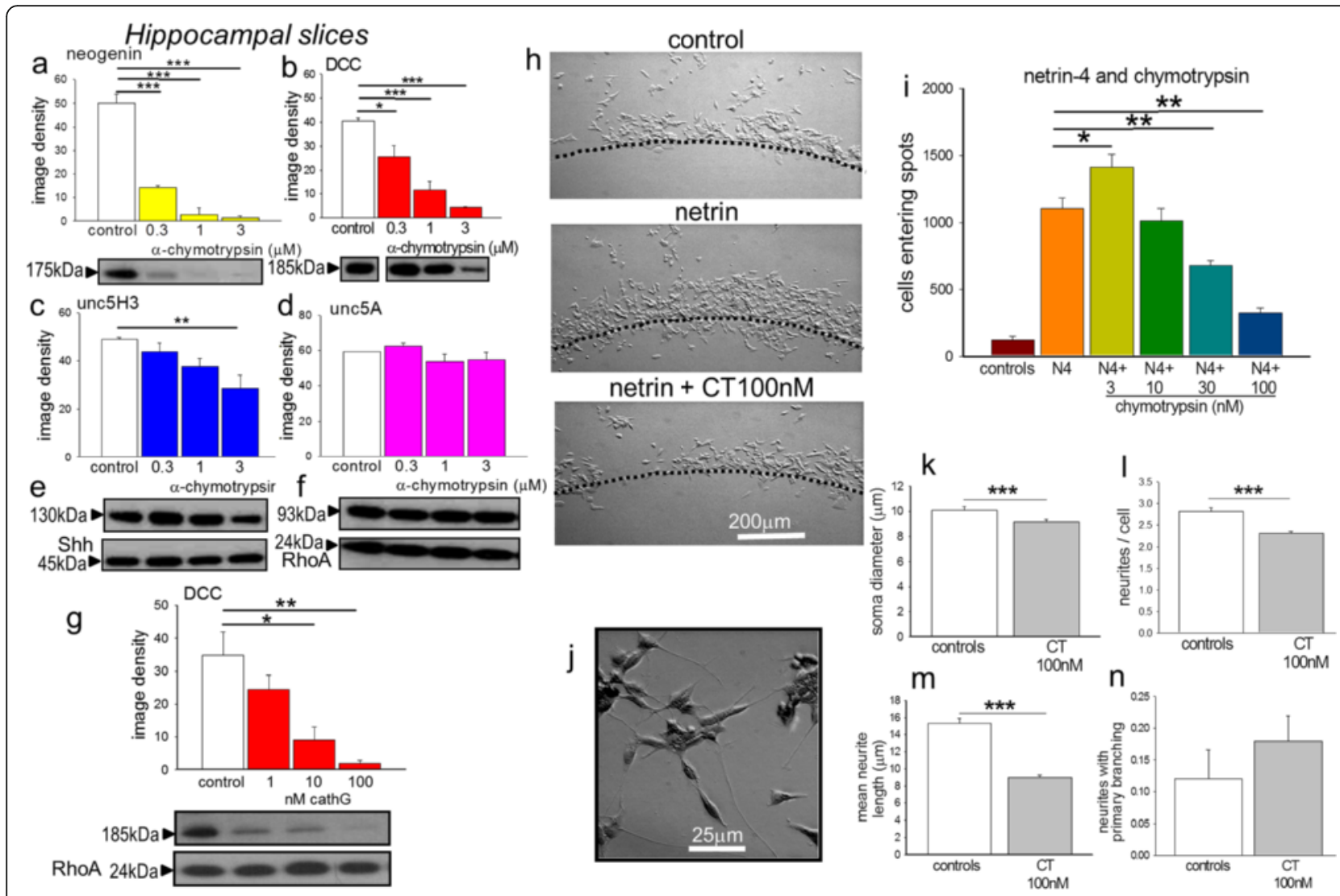

Fig. 2 Effects of chymotrypsin on protein expression. Protein expression in extracts of brain slices is summarised as image densities (arbitrary units) of Western blots quantified using Image J for the effects of chymotrypsin on (a) neogenin, (b) DCC, (c) Unc-5C, (d) Unc-5A, (e) Shh and (f) RhoA expression. Sample blots are shown below each chart, which illustrate the concentration-dependent effects of chymotrypsin. Chart (g) shows the depletion of DCC by the chymotryptic protein cathepsin G in tissue slices. Panels (h) illustrate the agarose spot assay to study the migration of SH-SY5Y cells towards netrin-4. The spot border is indicated by the dotted line. The accumulation of cells on the outside of a normal spot is shown in the top micrograph (control), with the penetration of cells into the spot induced by netrin-4 (netrin, middle micrograph) and reduced penetration in the presence of chymotrypsin (netrin $+C T 100 \mathrm{nM}$ ). The number of cells entering the spots is summarised in chart (i). Photograph (j) is of SH-SY5Y cells used for the measurement of neurite growth after staining with cresyl violet, with bipolar and multipolar cells visible. The accompanying bar charts summarise the measurements of soma diameter $(\mathbf{k})$, neurites per cell (I), mean neurite length $(\mathbf{m})$ and the proportion of neurites with primary branching $(\mathbf{n})$. Bars in charts (a) to (i) represent mean \pm s.e.mean $(n=4)$. ${ }^{*} P<0.05 ; * * P<0.01 ; * * P<0.001$ relative to the control bar. Calibration bars: $200 \mu \mathrm{m}$ in (h), $25 \mu \mathrm{m}$ in (j)

response, showed a similar effect, reducing DCC protein expression at concentrations of $10 \mathrm{nM}$ or above (Fig. 2g).

\section{Cell migration}

In addition to its role in cell survival, netrin provides a chemoattractive stimulus for the movement of cells. The attraction is mediated by netrin binding to DCC or neogenin and is increased by over-expression of these receptors and prevented in some tissues by DCC antibodies or anti-sense RNA [73, 74].

Cell migration studies using netrin incorporated into an agarose gel spot, showed that SH-SY5Y neuroblastoma cells moved towards netrin (Fig. $2 \mathrm{~h}$,i) over a period of $24 \mathrm{~h}$ [59]. Since the levels of DCC are low in cancerderived cell lines, netrin- 4 was used in these experiments, since this is an effective ligand for neogenin, which is abundant in SH-SY5Y neuroblastoma cells. In the presence of netrin-4, the number of cells reaching the agarose spot increased approximately 10 -fold relative to control wells (Fig. 2i). The addition of chymotrypsin at $3 \mathrm{nM}$ produced a small enhancement of migration, while at $10 \mathrm{nM}$ or above chemotaxic migration was inhibited (Fig. 2i) consistent with previous data [36] and with its suppression of DCC and neogenin expression. The initially increased attraction probably results from the relative amounts of DCC and neogenin in the cells since neogenin is a target of both netrin and the Repulsive Guidance Molecules. Since chymotrypsin is slightly more potent in reducing neogenin than DCC expression (Fig. 2a,b), this would unmask the net attractive effect of DCC in the absence of neogenin. 
These effects of chymotrypsin were associated with changes in neuronal morphology. DCC and neogenin are involved in neurite or growth cone formation and collapse essential for axonal guidance [74-76]. When exposed to chymotrypsin at $100 \mathrm{nM}$ for up to $72 \mathrm{~h}$, SH-SY5Y cells (Fig. 2j) exhibited a significant reduction in soma diameter (Fig. 2k), the number of neurites per cell (Fig. 2l) and the mean length of neurites (Fig. 2m). There was also a trend to increase neuritic branching (Fig. 2n). Such changes in neuritic parameters are consistent with the proposed involvement of DCC and neogenin in the regulation of neurite elongation and branching $[73,77,78]$ and support the concept that the depletion of dependence receptors by subtilisin and chymotrypsin has the expected functional consequences.

\section{Wound healing assays}

Migration was also studied using MCF-7 cells in the wound or scratch assay $[60,61]$, MCF-7 cells exhibit a lower basal level of motility than MDA-MB-231 cells and the latter line includes significant numbers of floating cells which complicate interpretation of the results. At $100 \mathrm{nM}$, subtilisin increased the rate of closure of the scratch wound compared with control cells over $72 \mathrm{~h}$ (Fig. 3a-c). Protein expression in these cells showed sensitivity to subtilisin and chymotrypsin similar to that of the adult brain tissue and neuroblastoma cells, with subtilisin at $100 \mathrm{nM}$ producing a substantial reduction in neogenin expression (Fig. 3d) but no change of unc-5C or RhoA expression (Fig. 3e, f).

Chymotrypsin showed a similar ability to facilitate wound closure over $72 \mathrm{~h}$ (Fig. 3g-i). As in the preceding work, chymotrypsin $(1 \mu \mathrm{M})$ was less effective than subtilisin but still reduced neogenin expression by $40 \%$ compared with control cultures after $48 \mathrm{~h}$ exposure (Fig. 3j) while having no effect on unc-5C (Fig. 3k) or RhoA (Fig. 3l).

The involvement of chymotryptic protease activity in the effect of subtilisin was confirmed by showing that chymostatin, the most selective chymotryptic inhibitor available, could prevent the facilitation of wound closure by subtilisin (Fig. 3m-p).

Similarly, the Bowman-Birk inhibitor from soybean (see below) at the relatively low concentration of $50 \mu \mathrm{M}$ was able to block completely the facilitation of wound closure by chymotrypsin (Fig. 3q-t). This concentration was used since higher levels can directly affect cell migration, complicating interpretation of the results. Even at this low concentration, however, the inhibitor showed a strong tendency to block the promotion of wound closure produced by subtilisin, which just failed to reach statistical significance $(P=0.06)$ (data not shown).
Cell proliferation was examined using the bromodeoxyuridine (BrdU) uptake method. After $2 \mathrm{~h}, 6 \mathrm{~h}$ or $24 \mathrm{~h}$ exposure neither subtilisin (30 or $100 \mathrm{nM}$ ) nor chymotrypsin (300 or $1000 \mathrm{nM})$ had any effect on the proliferation of MCF-7 cells (Fig. 4), indicating that changes in proliferation could not account for their efficacy on wound healing.

\section{Reversibility of cell behaviour}

An important property of many cells in culture is anoikis the induction of apoptosis when they become detached from a tissue or artificial substratum [79]. This behaviour mimics the in vivo propensity of cells to undergo apoptosis if they become detached from their home tissue, a phenomenon thought to protect organisms by preventing the migration of potentially abnormal cells to a distant site where they may become overtly oncogenic and establish metastases. To examine the effects of serine proteases we used the relatively aggressive human breast adenocarcinoma cell line of MDA-MB-231 cells. These cells normally exist as a mixture of flattened, multipolar or spindleshaped adherent cells (Fig. 5a, b(i)-(iv)) with some detached and floating cells. When subtilisin was added to cultures for $24 \mathrm{~h}$ at concentrations of $1 \mu \mathrm{M}$, a large proportion of cells detached from the culture plate and appeared as spherical cells floating in the medium, mostly as individual cells (Fig. $5 b(v)$ ), which could be maintained for up to $24 \mathrm{~h}$ (in $15 \%$ serum). When washed in fresh medium and transferred to new wells within $24 \mathrm{~h}$, the cells re-attached once more and then grew and divided as apparently normal cells, reforming the normal mixture of flat and rounded, adherent cultures (Fig. 5b(vi)). These observations indicate that the exposure of cells to subtilisin for $24 \mathrm{~h}$ did not produce irreversible cell toxicity, permanent damage or death and that the loss of adhesion was an acute and reversible phenomenon.

These observations were further supported by an examination of protein expression. In the presence of subtilisin there was a loss or profound reduction in the expression of neogenin and unc-5C, with preservation of RhoA levels (Fig. 5c), but after washing and re-plating, protein expression recovered to their original levels within $24 \mathrm{~h}$, in parallel with the recovery of normal cell morphology (Fig. 5c). These results agree with previous data showing that mutational silencing or deletion of DCC or neogenin using siRNA techniques can produce a loss of cell adhesion leading to detachment [80, 81] supporting the concept that biologically relevant serine proteases can have the same net effects as this highly selective experimental inactivation protocol. Most importantly, the reversibility of cell detachment and dependence receptor depletion by serine proteases reinforces the potential relevance of our observations to cancer cell dispersion and formation of metastases. 

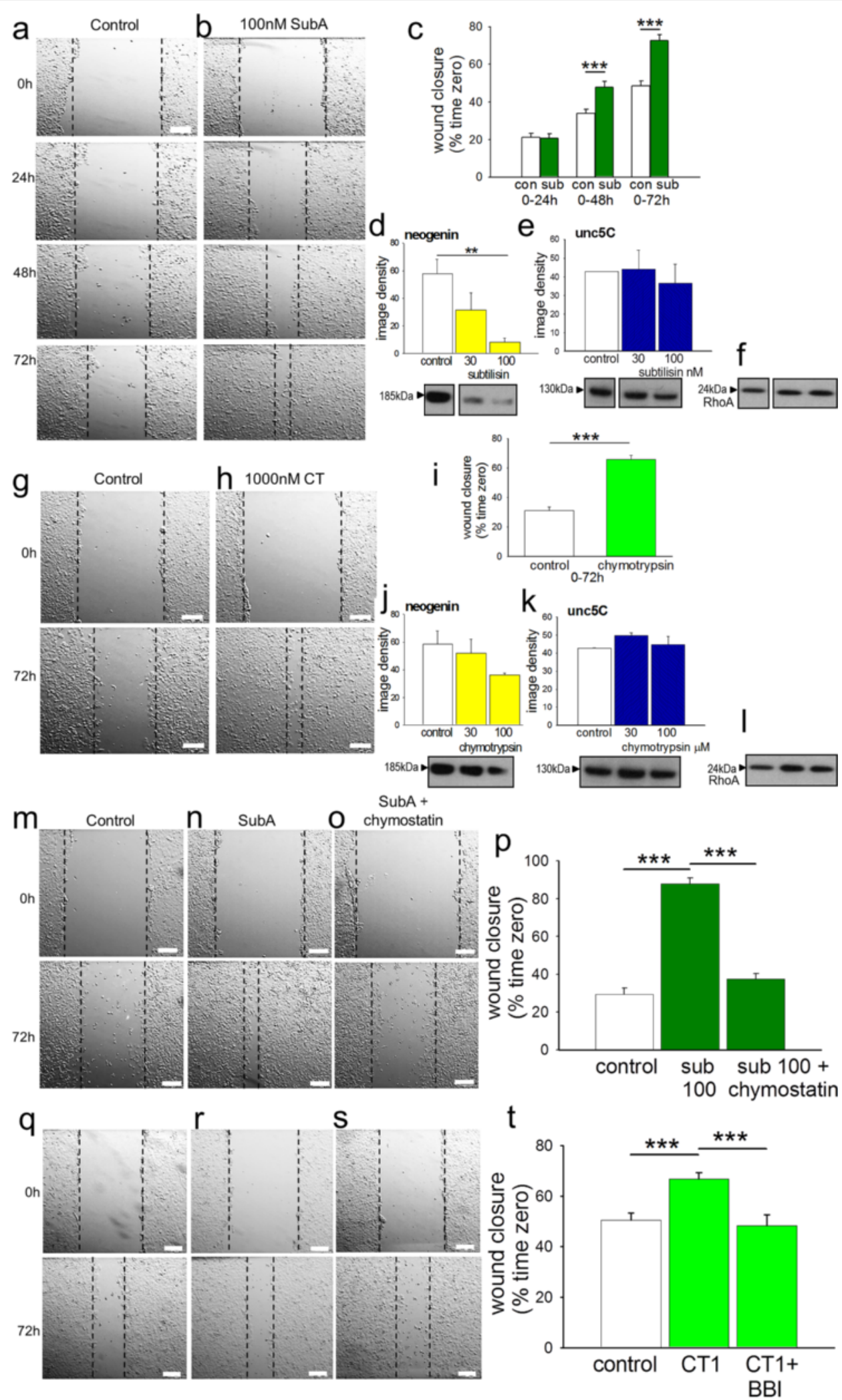

Fig. 3 (See legend on next page.) 
(See figure on previous page.)

Fig. 3 Effects of serine protease inhibitors on wound closure. At 100nM subtilisin promotes the closure of a scratch wound in MCF-7 cultures between $\mathrm{O} \mathrm{h}$ and $72 \mathrm{~h}$ relative to the closure rate in untreated cells $(\mathbf{a}, \mathbf{b})$. The quantified scratch closure data are summarised in chart (c). The effect of subtilisin at 30 and 100nM is shown on the expression of (d) neogenin, (e) unc-5C, (f) RhoA in the same cell line of MCF-7 breast adenocarcinoma cells. Chymotrypsin $(1 \mu \mathrm{M})$ shows a similar ability to facilitate wound closure $(\mathbf{g}, \mathbf{h})$ as summarised in panel (i). Chymotrypsin has a similar but weaker action on neogenin expression (j) without affecting unc-5C ( $\mathbf{k}$ ) or RhoA (I). In separate experiments $(\mathbf{m})$ the rate of wound closure is again facilitated by subtilisin $(\mathbf{n})$ whose effect is blocked by the chymotryptic protease inhibitor chymostatin $(\mathbf{o}, \mathbf{p})$. Similarly the Bowman-Birk inhibitor from soybean was able to completely block the facilitation of cell migration produced by chymotrypsin $(\mathbf{q}-\mathbf{t})$. Bars represent mean \pm s.e.mean of the percentage change in wound area $(n=3-4) .{ }^{* *} P<0.01 ;{ }^{* *} P<0.001$ relative to the control bar. Calibration bars: $200 \mu \mathrm{m}$

\section{Down-regulation of ectopic DCC}

While tissue slices expressed high levels of DCC and neogenin, the cancer-derived cell lines showed little or no intrinsic DCC expression. We therefore inserted the $d c c$ gene into SH-SY5Y and MCF-7 cells to generate a population of transiently transfected cells which exhibited much stronger fluorescence than control cells (Fig. 6a-c). Western blots confirmed the very low levels of DCC in naïve cells with approximately 25 -fold higher expression in the transfected cells (Fig. 6d). Levels of neogenin and RhoA were not different between control and transfected cells (Fig. 6e, f) confirming that they were not directly affected by the introduction of DCC. The addition of subtilisin (30 or 100nM for $48 \mathrm{~h}$ ) showed a clear suppression of both ectopic DCC expression (Fig. 6d) and of endogenous neogenin (Fig. 6e) with no effect on RhoA (Fig. 6f). Comparable results were obtained using transfected MCF-7 cells, with a reduction in ectopic DCC expression at 100nM subtilisin (Fig. 6g), but no change in RhoA (Fig. 6h).

\section{Bowman-Birk and other inhibitors}

Families of Bowman-Birk serine protease inhibitors have been isolated from a wide range of plants, including the soybean inhibitor from Glycine max [48-51]. They have

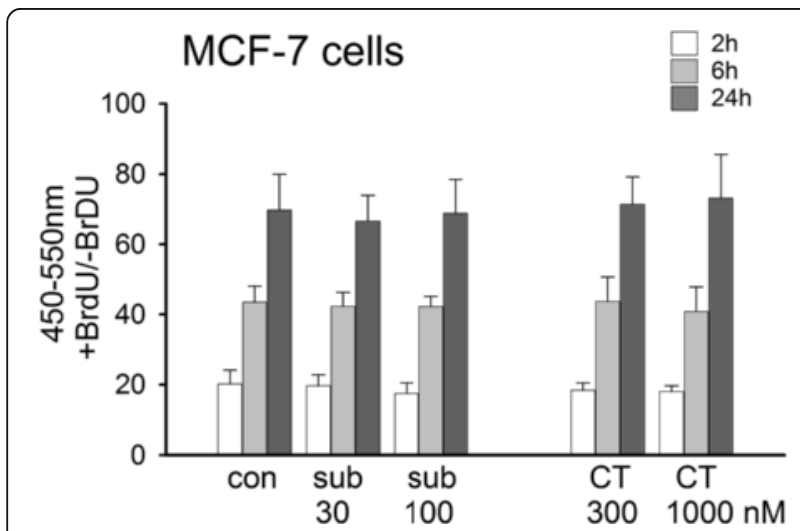

Fig. 4 Proliferation of MCF-7 cells. Using the BrdU for cell proliferation, neither subtilisin 30 or 100nM, nor chymotrypsin 300 or $1000 \mathrm{nM}$ had any effect on the proliferation of MCF-7 breast cancer cells after 2, 6 or $24 \mathrm{~h}$ incubation with the protease $(n=3)$ anti-cancer properties associated with their inhibitory activity against trypsin-like and chymotrypsin-like enzymes $[51,82]$. We found that the soybean protease reduced significantly the loss of DCC produced by chymotrypsin (Fig. 7a) without affecting the expression of other proteins such as neogenin, RhoA or Shh (Fig. 7b-d).

To examine the effect of the soybean Bowman-Birk inhibitor on a functional system, it was tested on the wound invasion assay. As noted above and shown in Fig. 3q-t, the inhibitor $(50 \mu \mathrm{M})$ blocked completely the facilitation of wound closure produced by chymotrypsin $(1 \mu \mathrm{M})$ and substantially reduced the effect of subtilisin $(P=0.06)$.

Although DCC and neogenin can be metabolised by $\gamma$-secretase activity [83-85], the $\gamma$-secretase inhibitor $N$-[N-(3,5-difluorophenacetyl-L-alanyl)]-(S)-phenylglycine$t$-butyl ester (DAPT; $5 \mu \mathrm{M}$ ) did not modify the basal expression of DCC or neogenin or their depletion by chymotrypsin (Fig. 7a-d). The bacterial chymotryptic inhibitor chymostatin blocked the effects of chymotrypsin and subtilisin on DCC (Fig. 7e) and neogenin (Fig. 7f). Selective inhibitors of proteasomal chymotryptic activity carfilzomib [86-88], epoxomicin (epox, $1 \mu \mathrm{M}$ ) [89, 90] and carbobenzoxy-Leu-Leu-leucinal (MG132, $10 \mu \mathrm{M})$ [91] - did not affect DCC or neogenin expression (Fig. 7g-j) although carfilzomib did reduce significantly the effect of chymotrypsin.

Another endogenous serine protease, trypsin, also reduced the expression of neogenin (Fig. 7k) and DCC, (Fig. 7l) with no significant effects on Unc-5C, Unc-5A, Shh and RhoA expression (Fig. $7 \mathrm{~m}$ ). These effects were not prevented by $\mathrm{N}$ - $\alpha$-tosyl-L-lysine-chloromethyl-ketone (TLCK) - an inhibitor of trypsin-like enzymes, or the general inhibitor of chymotryptic proteases, N-tosyl- Lphenylalanyl-chloromethyl-ketone (TPCK) (Figs. 7k, l).

TPCK, but not TLCK, blocked the effect of chymotrypsin on neogenin expression (Additional file 1: Figure S1a, b) and increased DCC to a level not significantly different from controls (Additional file 1: Figure S1b). Neither TPCK nor TLCK blocked the effects of subtilisin on DCC or neogenin (Additional file 1: Figure S1c, d) indicating that subtilisin is atypical, despite its blockade by chymostatin (see Fig. 7e, f).

Although DCC and neogenin can also be degraded by matrix metalloprotease-9 (MMP-9) [83, 84, 92], a 


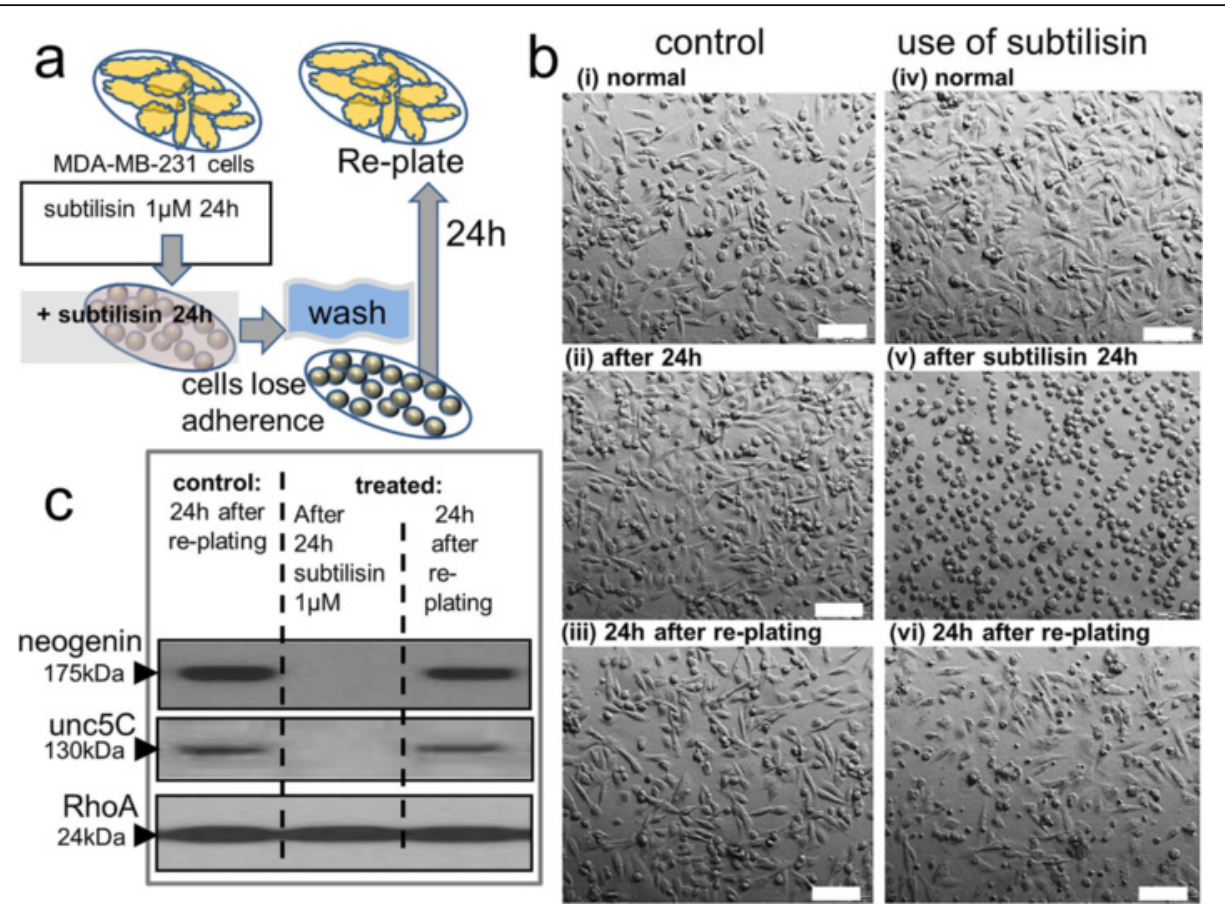

Fig. 5 Reversibility of subtilisin. Panel (a) illustrates the experimental paradigm. MDA-MB-231 cells, as a mixture of flattened and rounded cell types attached to the dish together with some detached, floating cells $(\mathbf{b}(\mathrm{i})$,(iv)), were treated with a relatively high concentration of subtilisin $(1 \mu \mathrm{M})$ for $24 \mathrm{~h}$. This caused most cells to detach from the culture plate and appear as spherical cells floating in the culture medium either as individual cells $(\mathbf{b}(\mathrm{v}))$ or as aggregates. After $24 \mathrm{~h}$, the cells were washed in fresh medium and transferred to new wells, where the detached cells re-attached to the well surface and grew to reform the apparently normal mixture of flat and rounded, adherent cultures (b(vi)). Control cells were treated similarly by washing (b(ii)) and transference to new wells (b(iii)) in parallel with the subtilisin-treated dishes. The ability to recover from subtilisin treatment was supported by protein expression (c). There was a substantial reduction in the expression of neogenin and unc-5C, with preservation of RhoA levels (c) in the presence of subtilisin. When the cells were washed and re-plated as above, expression of these proteins recovered to their orginal levels within $24 \mathrm{~h}$, in parallel with the recovery of normal cell morphology. Scale bar: $100 \mu \mathrm{m}$

selective inhibitor of MMP-9 (2-((4-phenoxyphenylsulfonyl)-methyl) thiirane); SB-3CT) did not alter expression of the dependence receptors or prevent their downregulation by chymotrypsin (Additional file 1: Figure S2A, B). The non-selective MMP inhibitor marimastat $(10 \mu \mathrm{M})$ was also ineffective in blocking the protease activity (Additional file 1: Figure S2a,b).

\section{Discussion}

The present results reveal the ability of endogenous chymotrypsin and an environmental, bacterial chymotryptic protease, subtilisin, to down-regulate DCC and neogenin expression, increasing cell migration. The reversibility of the changes in adhesion and protein expression would be relevant for cells to migrate and form metastases elsewhere. Other proteins with strong functional links with DCC were unaffected.

Even in prokaryotes, serine proteases are involved in the control of proliferation and modulation of the cell cycle [93] and an association with cancer was recognised some years ago [94-98]. Chymotrypsin and related enzymes increase proliferation and migration [35, 99-104] and high levels occur in several cancers, especially in mammary myoepithelial cells and some solid tumours [105-108], correlating with the development of malignant disease. Tumour cell aggression is correlated with serine protease activity in models of carcinogenesis and metastasis [109-111]. Conversely, serine protease inhibitors or enzyme down-regulation reduce cell migration and invasiveness [82, 112-114] while reduced levels of serine protease inhibitors promote oncogenesis [42]. Trypsin is also linked with the development of cancers [36] including pancreatic adenocarcinoma [115] and colorectal cancer, cases of the latter showing poor patient prognosis correlating with their trypsin content $[116,117]$. Indeed, serine proteases are involved in a wide range of biological activities [118] including embryonic development, osteogenesis, and immune cell function, making the present results potentially of far wider physio-pathological significance than only for cancer.

\section{Dependence receptors}

The experimental deletion or disruption of the $d c c$ gene can induce or promote cell migration and invasiveness [11-14] while transfecting cells with the gene can reduce these characteristics $[13-17,80]$. Neogenin expression is 


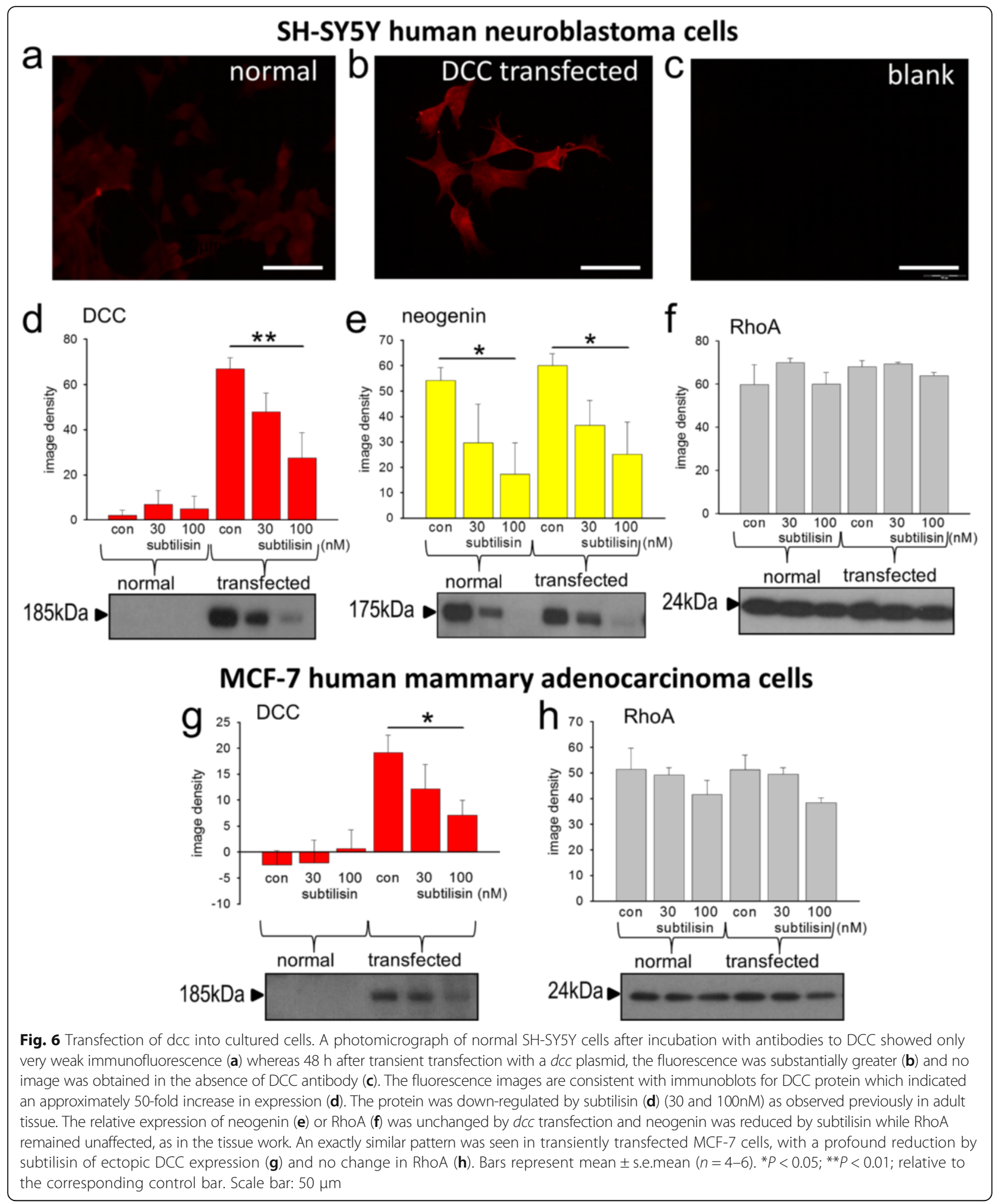

also reduced in tumours, especially those involving mammary tissue [20,25], where it regulates cell proliferation, migration and invasion [119]. Over-expression can suppress abnormal proliferation and migration $[22,23]$. The third netrin receptor (unc-5C) is also involved in cell proliferation and migration and is reduced in many cancers $[33,46,64,120]$. However, since there are few mutations of the respective genes in cancerous cells, non-genetic 


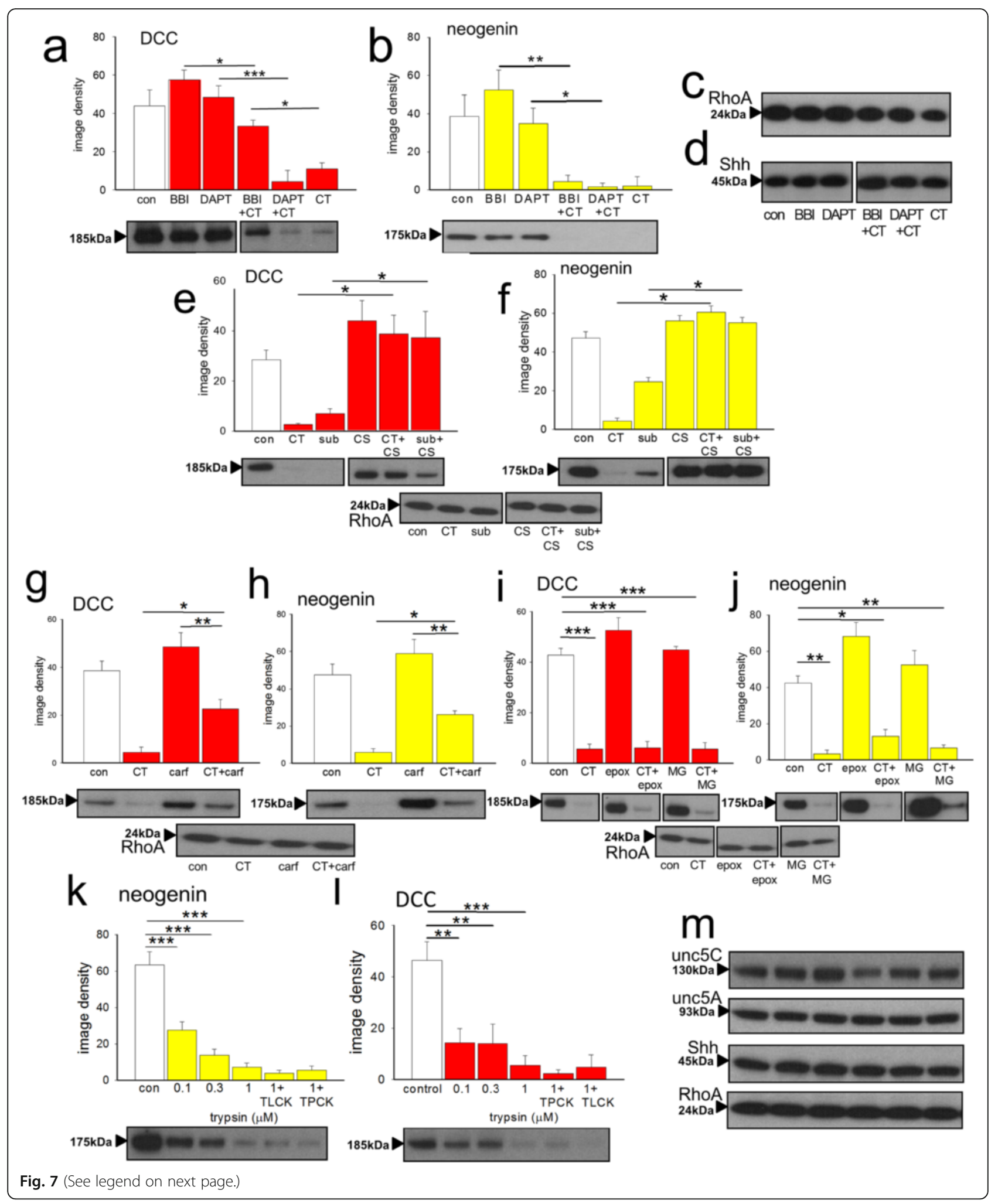


(See figure on previous page.)

Fig. 7 Potential inhibitors of serine proteases. Protein expression in extracts of brain slices is summarised as image densities (arbitrary units) of Western blots quantified using Image J for the effects of chymotrypsin $(C T, 1 \mu M)$ on DCC (a), neogenin (b), RhoA (c) and Shh (d) expression. Sample blots are shown below each chart, which illustrate the concentration-dependent effects of the proteases. The Bowman-Birk soybean inhibitor (BBI, $100 \mu \mathrm{M}$ ) blocked the effect of chymotrypsin on DCC expression (a) although the $\gamma$-secretase inhibitor DAPT (5 $\mu \mathrm{M})$ did not prevent the loss of DCC (c) or neogenin (d). Neither BBI nor DAPT had any effect themselves on protein expression. Chymostatin (CS, 30 HM) had no significant effect alone but blocked the inhibitory effects of both chymotrypsin and subtilisin on DCC (e) and neogenin (f) expression. The chymotryptic proteasome inhibitor carfilzomib (carf, 50nM) significantly reduced the effect of chymotrypsin $(C, 1 \mu \mathrm{M})$ on DCC (g) and neogenin (h) expression. However, two other inhibitors of the 20S proteasome, epoxomicin (epox, $1 \mu \mathrm{M}$ ) and MG132 (MG, $10 \mu \mathrm{M}$ ) had no significant effect themselves and did not block the effect of chymotrypsin on DCC (i) or neogenin (j). Trypsin reduced the expression of neogenin ( $\mathbf{k}$ ) and DCC (I) with no significant effects on unc5H3, unc5H1, Shh and RhoA expression $(\mathbf{m})$ but these effects were not prevented by TPCK or TLCK. Sample blots are shown below each chart. Bars represent mean \pm s.e.mean $(n=4) .{ }^{*} P<0.05 ;{ }^{*} P<0.01 ;{ }^{* * *} P<0.001$ relative to the control bar

modifications may be sufficient to cause cellular dysfunction $[9,10]$, a conclusion consistent with growing evidence that non-genetic factors play a dominant role in oncogenesis [121-123]. The down-regulation of DCC and neogenin by serine proteases could be one example of the several processes involved [58].

\section{Chymotrypsin and cancer}

Chymotryptic activity is present in the blood and other tissues in the form of chymotrypsin and related proteins such as chymase and cathepsins released from neutrophils during inflammation. Chymotrypsin can also be absorbed, along with other large proteins, from the intestinal contents into the blood [124]. As a result these endogenous proteases are in direct contact with most organs and tissues (Fig. 8). Chymotrypsin is resistant to destruction in the gut in order to carry out its digestive functions and its concentration in the intestinal contents changes little from pancreas to faeces, enabling faecal chymotrypsin concentrations to be used as an indicator of pancreatic function [125-128]. The concentrations of chymotrypsin in normal human chyme and faeces are around 1-10 $\mu \mathrm{M}$ [129-131], levels similar to, and often higher than those able to deplete neogenin and DCC. It is likely, therefore, that this depletion also occurs in vivo, its impact normally limited by the continual replacement of intestinal epithelial cells or a plant-rich diet. Slowed transit times or the regular consumption of proteasetreated meat products may increase the impact of chymotryptic activity on dependence receptor expression.

Chymotrypsin production is increased in obese individuals, partly in proportion to food volume in order to process the protein content and partly in response to a raised consumption of meat, which has a higher proportion of protein per unit weight than dietary plants. Changing to a vegan diet reduces the secretion of chymotrypsin and the intestinal

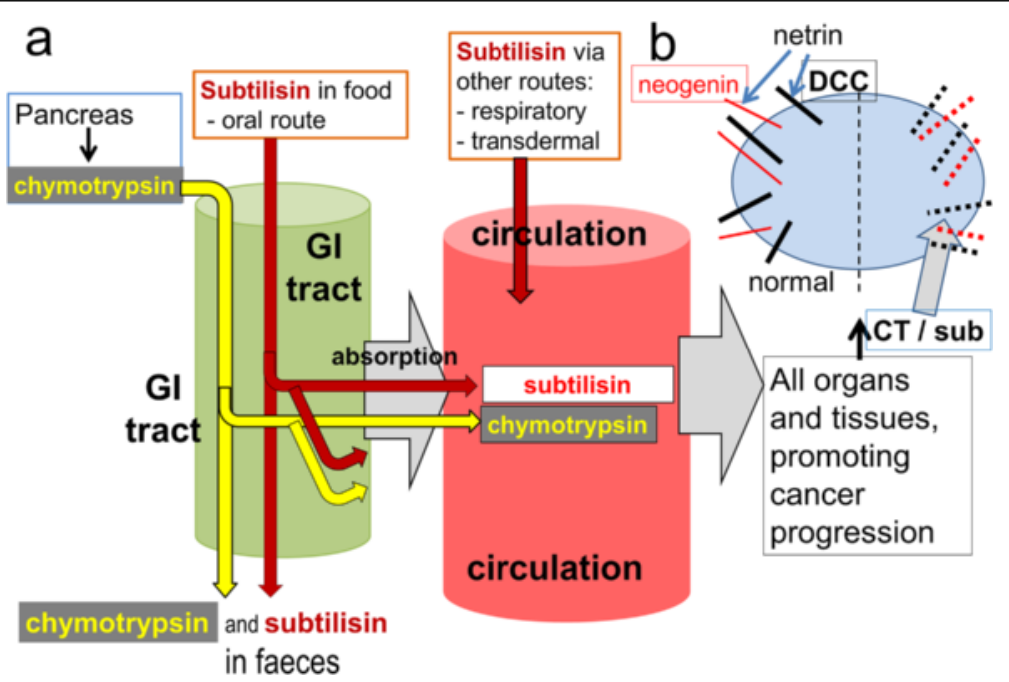

Fig. 8 A schematic summary of the hypothesis. a The pancreas secretes chymotrypsin (yellow) as a digestive enzyme in proportion to the amount of food (protein) consumed. Most passes through the gastro-intestinal (GI) tract unchanged. Subtilisin present in processed foods as well as Bacillus subtilis present in soil, livestock feed and probiotics, enter the gastro-intestinal tract orally, while subtilisin present in cleaning products may access the body via the respiratory system or dermal contact. Both proteases will be in contact with cells in the intestinal epithelium and some will be absorbed into the cardiovascular circulation from where both will access all organs and tissues, promoting oncogenesis. $\mathbf{b}$ At the cellular level netrin promotes cell stability and proliferation, with DCC acting to inhibit that activity. The unhindered activity of DCC induces cell death, partly by apoptosis. When DCC is removed by subtilisin or chymotrypsin, netrin can promote proliferation leading potentially to cancer 
concentration [126], consistent with the lower colorectal cancer levels in vegetarians [132].

\section{Subtilisin, diet and cancer}

Subtilisin is a chymotryptic serine protease synthesised and secreted by B. subtilis and related species. Closely related enzymes with similar substrate specificities are secreted by other bacteria (Streptomyces spp and Cryptosporidium spp) [133-135] as well as some fungi and yeasts (Aspergillus spp [136, 137], Cryphonectria parasitica [138] and Trichoderma reesei), the latter secreting particularly large quantities of a subtilisin-like protease [139].

B. subtilis itself is ubiquitous in the environment and in high densities in soil. It is a normal commensal bacterium in the mammalian intestine $[47,140,141]$ since the bacteria and spores resist destruction in the stomach and intestine [142] (Fig. 7). The bacteria are included in many probiotic preparations for use in humans or farming livestock to promote digestion and to increase muscle mass [140, 143-147] (approximately 1,000 tonnes of the enzyme are used annually in Europe alone [148]). High densities of the bacteria are observed in abattoirs and food-processing plants $[149,150]$ where it is sometimes used to tenderise meats and to promote compaction after butchering. Since the bacteria are highly resistant to acidity or temperature changes (including boiling), subtilisin of bacterial or environmental origin which enters the food chain represents a candidate for mediating the effects of diet and environment on cancer generation by depleting cellular DCC and neogenin. Being of similar molecular size to chymotrypsin and smaller then ferritin, subtilisin is also likely to be absorbed from the intestine [124] into the systemic blood from where it would reach all the organs and tissues and potentially promote cancer development at those sites.

The enzyme is also used in some cleaning preparations and exfoliants. The US Household Products Database catalogues more than 100 domestic cleaning products which contain subtilisin [151] and others are available elsewhere. Such sources represent a further route of biological access for subtilisin in the industrial and domestic environments.

\section{Protease inhibitors}

The case for a serine protease involvement in cancer (Fig. 8) is strongly supported by the prevention of dependence receptor loss by a Bowman-Birk inhibitor. These compounds are selective inhibitors of serine proteases [152] and are produced by many species of plant including soybeans, lentils [48], wheat [153], potatoes [49, 154] and other sources $[50,155]$. They are highly resistant to heat and metabolism, passing largely unchanged through the gut after dietary consumption. Importantly, the inhibitor was also able to prevent the increase in cell migration produced by chymotrypsin in the wound assay, and partly reduced the effect of subtilisin when used at a low concentration. These actions would be consistent with the protective anti-cancer effects of a plant-rich diet. This may be especially important in preventing metastasis formation since this is dependent on serine proteases released from neutrophils which have been attracted to areas of inflammation [156] and which are inhibited by Bowman-Birk inhibitors [157]. These inhibitors have been shown previously to have anti-cancer activity in vitro $[158,159]$ and in humans and other animals. After oral administration they can suppress the development not only of intestinal cancers [160, 161] but also those in other tissues after absorption from the gut [162-165]. A concentrated plant extract of Bowman-Birk inhibitors has proved effective in human clinical trials [51], although a precise site of action had not previously been identified [166].

\section{Cancer prevention and public health}

Further work is required to establish the precise relationship between continually elevated concentrations of subtilisin and chymotrypsin in the blood after chronic, continual, oral administration, their selective removal of dependence receptors, and the development of cancers in vivo, especially in relation to the development of latestage and malignant disease. In addition to providing an explanation of a major environmental influence on cancer development, these relationships might justify the clinical use of protease inhibitors in combination with existing radiotherapy and chemotherapy. Thus, if the presence of subtilisin in the environment and food chain could be reduced so that the progression of tumours to malignancy was slowed or prevented, conventional agents should be able more effectively to produce a complete elimination of the disease.

Overall, our results suggest the hypothesis that lifestyle factors such as food choice may make a contribution to cancer incidence and malignancy [122]. They also suggest a socio-economically valuable public health strategy. Eliminating the use of subtilisin in farming livestock and meat processing, domestic cleaning preparations and other sources in the environment, encouraging careful washing of crops and increasing the dietary intake of plant-sourced serine protease inhibitors, could potentially reduce the worldwide incidence of several forms of cancer by reducing serine protease-induced removal of DCC and neogenin.

\section{Conclusions}

The present results show that two representative serine proteases, endogenous mammalian chymotrypsin and an environmental, bacterial chymotryptic protease, 
subtilisin, can down-regulate DCC and neogenin expression in cells, increasing cell migration. The reversibility of the changes in adhesion and protein expression would be important for cells which migrate from their home tissue to form metastases elsewhere. Since chymotrypsin secretion is increased by overeating and increased basal metabolic rate, and it can be absorbed from the intestine where is exists as a normal digestive enzyme, it may provide an explanation of the link between over-eating and cancer incidence. Subtilisin is used in meat tenderisation and processing, and domestic and industrial cleaning products, while its main producer, the bacterium $B$. subtilis, is added to probiotics and food for farm animals to promote growth. This relationship may contribute to the link between meat consumption and cancer incidence, while inhibition of chymotryptic enzymes by Bowman-Birk inhibitors from plants may explain the protective effects of a plantbased diet. The data reported here, therefore, may help understanding of the causes of many cancers, with the potential to prevent many of them by restricting the industrial and agricultural use of serine proteases. In addition, further work on the efficacy of dietary Bowman-Birk compounds as inhibitors of subtilisin and chymotrypsin might lead to their increased use as protection against cancer.

\section{Additional file}

Additional file 1: Supplementary material. Supplementary Figures S1, S2 and associated legends. (DOC $900 \mathrm{~kb}$ )

\begin{abstract}
Abbreviations
AEBSF: 4-(2-Aminoethyl) benzenesulfonylfluoride hydrochloride (AEBSF); AYPGKF-NH2: Ala-tyr-pro-gly-lys-phe-NH2 trifluoroacetate (Sigma A3227); BBI: Bowman-Birk protease inhibitor; BrdU: Bromodeoxyuridine; CSF: Cerebrospinal fluid; DAPT: N-[N-(3,5-Difluorophenacetyl-L-alanyl)]-(S)phenylglycine $t$-butyl ester; DCC: Deleted in colorectal cancer; DR(s): Dependence receptor(s); MAR: Marimastat; MG132: Carbobenzoxy-LeuLeu-leucinal; MMP: Matrix metalloprotease; RhoA: Ras homologue A; SB-3CT: 2-((4-phenoxyphenylsulfonyl)methyl) thiirane; Shh: Sonic hedgehog; TLCK: N-alpha-tosyl-L-lysine-chloromethylketone; TPCK: N-tosyl- L-phenylalanylchloromethyl-ketone (a-CT specific); Unc: Unco-ordinated locomotion (unc5-A-D in non-human animals these were formerly referred to as unc5H1-4)
\end{abstract}

\section{Acknowledgements}

We gratefully acknowledge the generous support for this work by Epsom Medical Research and the Estate of the late Mr. Aubrey M Spencer. We thank Dr. R. Spike for the neurite measurements and Dr. W. El-Bestawy for help with transfection. The work was based on initial observations during work supported by the Peacock Trust.

\section{Funding}

This work was funded by Epsom Medical Research and the Estate of the late Mr. Aubrey M Spencer. The work was based on initial observations during work supported by the Peacock Trust. The funding bodies played no part in the design of the study, collection, analysis, and interpretation of data.

\section{Availability of data and materials}

The data underlying the results and conclusions of this study are available on request from the Corresponding Author (Trevor.Stone@glasgow.ac.uk).

\section{Authors' contributions}

Conception and design: TWS, LGD; Development of methodology: TWS, CMF, KM, MCV; Acquisition of data: TWS, CMF, KM, MCV; Analysis and interpretation: TWS, CMF, KM, MCV; LGD; Writing and revisions of manuscript: TWS, CMF, KM, MCV; LGD. All authors read and approved the final manuscript.

\section{Competing interests}

The authors declare that they have no competing interests.

\section{Consent for publication}

Not applicable.

\section{Ethics approval and consent to participate}

This work was carried out under Project and Personal licences according to the regulations of the Animals (Scientific Procedures) act 1986 of the UK, administered and monitored by the Home Office. Ethical approval was obtained from the University of Glasgow Ethical Review panel for non-clinical research.

\section{Author details}

${ }^{1}$ College of Medical, Veterinary and Life Sciences, West Medical Building, University of Glasgow, Glasgow G12 8QQ, UK. ${ }^{2}$ Internal Medicine, Ashtead Hospital, Ashtead, Surrey KT21 2SB, UK.

Received: 7 April 2016 Accepted: 21 September 2016

Published online: 06 October 2016

\section{References}

1. Bamias A, Yu Z, Weinberger PM, Markakis S, Kowalski D, Camp RL, Rimm DL, Dimopoulos MA, Psyrri A. Automated quantitative analysis of DCC tumor suppressor protein in ovarian cancer tissue microarray shows association with beta-catenin levels and outcome in patients with epithelial ovarian cancer. Ann Oncol. 2006;17:1797-802

2. Akkiprik M, Ataizi-Celikel C, Dusunceli F, Sonmez O, Gulluodlu BM, Sav A, Ozer A. Clinical significance of p53, K-ras and DCC gene alterations in the stage I-II colorectal cancers. J Gastrointest Liver Dis. 2007;16:11-7.

3. Saegusa M, Hashimura M, Hara A, Okayasu I. Loss of expression of the gene deleted in colon carcinoma (DCC) is closely related to histologic differentiation and lymph node metastasis in endometrial carcinoma. Cancer. 1999;85:453-64.

4. Aschele C, Debernardis D, Lonardi S, Bandelloni R, Casazza S, Monfardini S, Gallo L. Deleted in colon cancer protein expression in colorectal cancer metastases: a major predictor of survival in patients with unresectable metastatic disease receiving palliative fluorouracil-based chemotherapy. J Clin Oncol. 2004:515:3758-65.

5. Bacolod MD, Barany F. Molecular profiling of colon tumors: the search for clinically relevant biomarkers of progression, prognosis, therapeutics, and predisposition. Ann Surg Oncol. 2011;18:3694-700.

6. Reyes-Mugica M, Lin P, Yokota J, Reale MA. Status of deleted in colorectal cancer gene expression correlates with neuroblastoma metastasis. Lab Invest. 1998;78:669-75.

7. Delloye-Bourgeois C, Fitamant J, Paradisi A, Cappellen D, Douc-Rasy S, Raquin MA, Stupack D, Nakagawara A, Rousseau R, Combaret V, Puisieux A, Valteau-Couanet D, Benard J, Bernet A, Mehlen P. Netrin-1 acts as a survival factor for aggressive neuroblastoma. J Exp Med. 2009;206:833-47.

8. Popat S, Houlston RS. A systematic review and meta-analysis of the relationship between chromosome 18q genotype, DCC status and colorectal cancer prognosis. Europ J Cancer. 2005:41:2060-70.

9. Kohno T, Sato T, Takakura S, Takei K, Inoue K, Nishioka M, et al. Mutation and expression of the DCC gene in human lung cancer. Neoplasia. 2000;2:300-5.

10. Sato K, Tamura G, Tsuchiya T, Endoh Y, Usuba O, Kimura W, et al. Frequent loss of expression without sequence mutations of the DCC gene in primary gastric cancer. Brit J Cancer. 2001;85:199-203.

11. Castets M, Broutier L, Molin Y, Brevet M, Chazot G, Gadot N, et al. DCC constrains tumour progression via its dependence receptor activity. Nature. 2012;482:534-7.

12. Narayanan R, Lawlor KG, Schaapveld RQJ, Cho KR, Vogelstein B, Tran PBV, et al. Antisense RNA to the putative tumor-suppressor gene DCC transforms rat-1 fibroblasts. Oncogene. 1992;7:553-61.

13. Duman-Scheel M. Deleted in colorectal cancer (DCC) pathfinding: axon guidance gene finally turned tumor suppressor. Curr Drug Targets. 2012;13:1445-53. 
14. Krimpenfort P, Song J-Y, Proost N, Zevenhoven J, Jonkers J, Berns A. Deleted in colorectal carcinoma suppresses metastasis in p53-deficient mammary tumours. Nature. 2012:482:538-40.

15. Velcich A, Corner G, Palumbo L, Augenlicht L. Altered phenotype of HT29 colonic adenocarcinoma cells following expression of the DCC gene. Oncogene. 1999:18:2599-606.

16. Klingelhutz AJ, Hedrick L, Cho KR, McDougall JK. The DCC gene suppresses the malignant phenotype of transformed human epithelial-cells. Oncogene. 1995;10:1581-6.

17. Kato H, Zhou Y, Asanoma K, Kondo H, Yoshikawa Y, Watanabe K, et al. Suppressed tumorgenicity of human endometrial cancer cells by the restored expression of the DCC gene. Brit J Cancer. 2000;82:459-66.

18. Berrar D, Sturgeon B, Bradbury I, Downes CS, Dubitzky W. Survival trees for analyzing clinical outcome in lung adenocarcinomas based on gene expression profiles: Identification of neogenin and diacylglycerol kinase alpha expression as critical factors. J Comput Biol. 2005;12:534-44.

19. Li VSW, Yuen ST, Chan TL, Yan HHN, Law WL, Yeung BHY, et al. Frequent inactivation of axon guidance molecule RGMA in human colon cancer through genetic and epigenetic mechanisms. Gastroenterology. 2009;137:176-87.

20. Wilson NH, Key B. Neogenin: One receptor, many functions. Intern J Biochem Cell Biol. 2007:39:874-8.

21. Sun KLW, Correia JP, Kennedy TE. Netrins: versatile extracellular cues with diverse functions. Development. 2011;138:2153-69.

22. Wu X, Li Y, Wan X, Kayira TM, Cao R, Ju X, et al. Down-regulation of neogenin accelerated glioma progression through promoter methylation and its overexpression in SHG-44 induced apoptosis. PLoS One. 2012;7:AR e38074.

23. Zhang QS, Liang F, Ke Y, Huo YP, Li MC, Li YY, et al. Overexpression of neogenin inhibits cell proliferation and induces apoptosis in human MDA-MB-231 breast carcinoma cells. Oncology Rep. 2015;34:258-64.

24. Srinivasan K, Strickland P, Valdes A, Shin GC, Hinck L. Netrin-1/neogenin interaction stabilizes multipotent progenitor cap cells during mammary gland morphogenesis. Develop Cell. 2003;4:371-82.

25. Lee JE, Kim HJ, Bae JY, Kim SW, Park JS, Shin HJ, et al. Neogenin expression may be inversely correlated to the tumorgenicity of human breast cancer. BMC Cancer. 2005;5AR:154

26. Cole SJ, Bradford D, Cooper HM. Neogenin: a multi-functional recepto regulating diverse developmental processes. Internat J Biochem Cell Biol. 2007;39:1569-75

27. Matsunaga E, Tauszig-Delamasure S, Monnier PP, Mueller BK, Strittmatter SM, Mehlen $P$, et al. RGM and its receptor neogenin regulate neuronal survival. Nat Cell Biol. 2004;6:749-55.

28. Matsunaga $E$, Nakamura $H$, Chedotal A. Repulsive guidance molecule plays multiple roles in neuronal differentiation and axon guidance. J Neurosci. 2006;26:6082-8

29. Fitzgerald DP, Cole SJ, Hammond A, Seaman C, Cooper HM. Characterization of neogenin-expressing neural progenitor populations and migrating neuroblasts in the embryonic mouse forebrain. Neuroscience. 2006;142:703-16.

30. Mehlen P, Llambi F. Role of netrin-1 and netrin-1 dependence receptors in colorectal cancers. Brit J Cancer. 2005;93:1-6.

31. Mehlen P, Guenebeaud C. Netrin-1 and its dependence receptors as original targets for cancer therapy. Curr Opin Oncol. 2010;22:46-54.

32. Rodrigues S, De Wever O, Bruyneel E, Rooney RJ, Gespach C. Opposing roles of netrin-1 and the dependence receptor DCC in cancer cell invasion, tumor growth and metastasis. Oncogene. 2007;26:5615-25.

33. Goldschneider D, Mehlen P. Dependence receptors: a new paradigm in cell signaling and cancer therapy. Oncogene. 2010;29:1865-82.

34. VanZomeren-Dohm A, Sarro J, Flannery E, Duman-Scheel M. The Drosophila netrin receptor frazzled/DCC functions as an invasive tumor suppressor. BMC Devel Biol. 2011;11:AR41.

35. Dong $X$, Chen J, Zhang Y, Cen Y. Mast cell chymase promotes cell proliferation and expression of certain cytokines in a dose-dependent manner. Molec Med Rep. 2012;5:1487-90.

36. Elzer KL, Heitzman DA, Chernin MI, Novak JF. Differential effects of serine proteases on the migration of normal and tumor cells: implications for tumor micro-environment. Integ Cancer Therap. 2008;7:282-94.

37. Del Rosso M, Fibbi G, Pucci M, D’Alessio S, Del Rosso A, Magnelli L, Chiarugi V. Multiple pathways of cell invasion are regulated by multiple families of serine proteases. Clin Exp Metastasis. 2002;19:193-207.

38. Matsunaga J, Shono M, Takahashi M, Tsuboi Y, Ogawa K, Yamada T. Regulation of lymphocyte proliferation by eosinophils via chymotrypsin-like protease activity and adhesion molecule interaction. Brit J Pharmacol. 2000;130:1539-46.

39. Montgomery N, Hill A, McFarlane S, Neisen J, O'Grady A, Conlon S, Jirstrom K, Kay EW, Waugh DJJ. CD44 enhances invasion of basal-like breast cancer cells by upregulating serine protease and collagen-degrading enzymatic expression and activity. Breast Cancer Res. 2012;14:AR84.

40. Chan HS, Chang SJ, Wang TY, Ko HJ, Lin YC, Lin KT, Chang KM, Chuang YJ. Serine protease PRSS23 is upregulated by estrogen receptor alpha and associated with proliferation of breast cancer cells. PLoS One. 2012;7: Are30397.

41. Guan HY, Liang WW, Liu J, Wei GH, Li H, Xiu LL, Xiao HP, Li YB. Transmembrane protease serine 4 promotes thyroid cancer proliferation via CREB phosphorylation. Thyroid. 2015;25:85-94.

42. Baba T, Kawaguchi M, Fukushima T, Sato Y, Orikawa H, Yorita K, Tanaka H, Lin CY, Sakoda S, Kataoka H. Loss of membrane-bound serine protease inhibitor HAl-1 induces oral squamous cell carcinoma cells' invasiveness. J Pathol. 2012;228:181-92.

43. Ohta T, Futagami F, Tajima H, Kitagawa H, Kayahara M, Nagakawa T, Miwa K, Yamamoto M, Iseki S, Nakanuma Y, Terada T. Inhibitory effect of a serine protease inhibitor, FOY-305 on the invasion and metastasis of human pancreatic cancers. Internat J Oncol. 1997:11:813-7.

44. Wang XL, Li Y, Cheng XY, Chi Q, Yao XK, Wu HJ, Lun YZ. Inhibitory effects of the recombinant human serine protease inhibitor hespintor on the proliferation, migration and invasion of hepatocellular carcinoma cells. Oncol Rep. 2015;33:729-36.

45. Gao HS, Ding ZM, Huang JF, Qiu XJ, Guo J, Sun G, et al. Serine protease inhibitor (SERPIN) B1 suppresses cell migration and invasion in glioma cells. Brain Res. 2015:1600:59-69.

46. Bernet A, Mazelin L, Coissieux M-M, Gadot N, Ackerman SL, Scoazec J-Y, et al. Inactivation of the UNC5C netrin-1 receptor is associated with tumor progression in colorectal malignancies. Gastroenterology. 2007;133:1840-8.

47. Hong HA, Khaneja R, Tam NMK, Cazzato A, Tan S, Urdaci M, et al. Bacillus subtilis isolated from the human gastrointestinal tract. Res Microbiol. 2009;160:134-43.

48. Caccialupi P, Ceci LR, Siciliano RA, Pignone D, Clemente A, Sonnante G. Bowman-Birk inhibitors in lentil: Heterologous expression, functional characterisation and anti-proliferative properties in human colon cancer cells. Food Chem. 2010;120:1058-68.

49. Valueva TA, Parfenov IA, Revina TA, Morozkina EV, Benevolensky SV. Structure and properties of the potato chymotrypsin inhibitor. Plant Physiol Biochem. 2012;52:83-90.

50. Cheung AHK, Wong JH, Ng TB. Trypsin-chymotrypsin inhibitors from Vigna mungo seeds. Protein Peptide Lett. 2009;16:277-84.

51. Kennedy AR. The Bowman-Birk inhibitor from soybeans as an anticarcinogenic agent. Amer J Clin Nutr. 1998;68S:1406S-12S.

52. Forrest CM, Darlington LG, Stone TW. Involvement of the proteasome and caspase activation in hippocampal long-term depression induced by the serine protease subtilisin. Neuroscience. 2013;231:233-46.

53. Forrest CM, Darlington LG, Stone TW. Examination of dependence receptor involvement in subtilisin-induced long-lasting depression and hippocampal plasticity. Neuroscience. 2016. in press.

54. Pisar M, Forrest CM, Khalil OS, MCNair K, Vincenten MCJ, Qasem S, Darlington LG, Stone TW. Modified neocortical and cerebellar protein expression and morphology following prenatal inhibition of the kynurenine pathway. Brain Res. 2014;1576:1-17

55. Forrest CM, Khalil OS, Pisar M, Darlington LG, Stone TW. Prenatal inhibition of the tryptophan- kynurenine pathway alters synaptic plasticity and protein expression in the rat hippocampus. Brain Res. 2013;1504:1-15.

56. Dittmer A, Dittmer J. Beta-actin is not a reliable loading control in western blot analysis. Electrophoresis. 2006;27:2844-5.

57. Goasdoue K, Awabdy D, Bjorkman AT, Miller S. Standard loading controls are not reliable for western blot quantification across brain development or in pathological conditions. Electrophoresis. 2016;37:630-4.

58. Hanahan D, Weinberg RA. Hallmarks of cancer: the next generation. Cell. 2011:144:646-74.

59. Wiggins HL, Rappoport JZ. An agarose spot for chemotactic invasion. Biotechniques. 2010:48:120-3.

60. Liang CC, Park AY, Guan J-L. In vitro scratch assay: a convenient and inexpensive method for analysis of cell migration in vitro. Nat Protoc. 2007;2:329-33. 
61. Goetsch KP, Niesler CU. Optimization of the scratch assay for in vitro skeletal muscle wound healing analysis. Anal Biochem. 2011;411:158-60.

62. T-scratch. http://cse-lab.ethz.ch/software. Accessed 23 Sept 2016.

63. Image J. http://rsb.info.nih.gov/ij/.

64. Thiebault K, Mazelin L, Pays L, Llambi F, Joly MO, Scoazec JY, et al. The netrin-1 receptors UNC5H are putative tumor suppressors controlling cell death commitment. Proc Natl Acad Sci U S A. 2003;100:4173-8.

65. Hong KS, Hinck L, Nishiyama M, Poo MM, Tessier-Lavigne M, Stein E. A ligand-gated association between cytoplasmic domains of UNC5 and DCC family receptors converts netrin-induced growth cone attraction to repulsion. Cell. 1999;97:927-41.

66. Muramatsu R, Nakahara S, Ichikawa J, Watanabe K, Matsuki N, Koyama R. The ratio of 'deleted in colorectal cancer' to 'uncoordinated-5A' netrin-1 receptors on the growth cone regulates mossy fibre directionality. Brain. 2010;133:60-75.

67. Kim D, Ackerman SL. The UNC5C netrin receptor regulates dorsal guidance of mouse hindbrain axons. J Neurosci. 2011;31:2167-79.

68. Picard M, Petrie J, Antoine-Bertrand J, Saint-Cyr-Proulx E, Villemure J-F, Lamarche-Vane N. Spatial and temporal activation of the small GTPases RhoA and Rac1 by the netrin-1 receptor UNC5a during neurite outgrowth. Cell Signalling. 2009;21:1961-73.

69. McNair K, Spike R, Guilding C, Prendergast GC, Stone TW, Cobb SR, Morris BJ. A role for RhoB in synaptic plasticity and the regulation of neuronal morphology. J Neurosci. 2010;30:3508-17.

70. Mitchell N, Petralia RS, Currier DG, Wang YX, Kim A, Mattson MP, Yao PJ. Sonic hedgehog regulates presynaptic terminal size, ultrastructure and function in hippocampal neurons. J Cell Sci. 2012;125-S15:4207-13.

71. Yao PJ, Petralia RS, Ott C, Wang YX, Lippincott-Schwartz J, Mattson MP. Dendrosomatic sonic hedgehog signaling in hippocampal neurons regulates axon elongation. J Neurosci. 2015;35:16126-41.

72. Hong M, Schachter KA, Jiang G, Krauss RS. Neogenin regulates sonic hedgehog pathway activity during digit patterning. Devel Dynamics. 2012;241:627-37.

73. Bouchard JF, Moore SW, Tritsch NX, Roux PP, Shekarabi M, Barker PA, et al. Protein kinase A activation promotes plasma membrane insertion of DCC from an intracellular pool: A novel mechanism regulating commissural axon extension. J Neurosci. 2004;24:3040-50.

74. Lin L, Rao Y, Isaacson O. Netrin-1 and slit-2 regulate and direct neurite growth of ventral midbrain dopaminergic neurons. Molec Cell Neurosci. 2005;28:547-55

75. Metzger M, Conrad S, Skutella T, Just L. RGMa inhibits neurite outgrowth of neuronal progenitors from murine enteric nervous system via the neogenin receptor in vitro. J Neurochem. 2007;103:2665-78.

76. Shekarabi M, Kennedy TE. The netrin-1 receptor DCC promotes filopodia formation and cell spreading by activating Cdc42 and Rac1. Molec Cell Neurosci. 2002;19:1-17

77. Fenteany G, Schreiber SL. Specific inhibition of the chymotrypsin-like activity of the proteasome induces a bipolar morphology in neuroblastoma cells. Chem \& Biol. 1996;3:905-12.

78. Kuo T-Y, Hong C-J, Hsueh Y-P. BCl11A/CTIP1 regulates expression of DCC and MAP1b in control of axon branching and dendrite outgrowth. Mol Cell Neurosci. 2009;42:195-207.

79. Gilmore AP. Anoikis. Cell Death Differ. 2005;12:1473-7.

80. Martin M, Simon-Assmann P, Kedinger M, Martin M, Mangeat P, Real FX, et al. DCC regulates cell adhesion in human colon cancer derived HT-29 cells and associates with ezrin. Europ J Cell Biol. 2006;85:769-83.

81. Pohl U, Hohne MW, Gerlich WH, Schaefer S. Morphological and functional effects of antisense RNA to the deleted in colorectal carcinoma (DCC) gene in a pancreatic carcinoma cell line. Cancer Lett. 1999;145:9-15.

82. Clemente A, del Carmen Arques M. Bowman-Birk inhibitors from legumes as colorectal chemopreventive agents. World J Gastroenterol. 2014;20:10305-15.

83. Taniguchi Y, Kim SH, Sisodia SS. Presenilin-dependent "gamma-secretase" processing of deleted in colorectal cancer (DCC). J Biol Chem. 2003;278: 30425-8.

84. Goldschneider D, Rama N, Guix C, Mehlen P. The neogenin intracellular domain regulates gene transcription via nuclear translocation. Mol Cell Biol. 2008;28:4068-79.

85. Kim SH, Ikeuchi T, Yu CJ, Sisodia SS. Regulated hyperaccumulation of presenilin-1 and the gamma-secretase complex - Evidence for differential intramembranous processing of transmembrane substrates. J Biol Chem. 2003;278:33992-4002.
86. Kuhn DJ, Chen Q, Voorhees PM, Strader JS, Shenk KD, Sun CM, et al. Potent activity of carfilzomib, a novel, irreversible inhibitor of the ubiquitin-proteasome pathway, against preclinical models of multiple myeloma. Blood. 2007;110:3281-90.

87. Stapnes C, Doskeland AP, Hatfield K, Ersvaer E, Ryningen A, Lorens JB, et al. The proteasome inhibitors bortezomib and PR-171 have antiproliferative and proapoptotic effects on primary human acute myeloid leukaemia cells. Brit J Rheumatol. 2007;136:814-28.

88. Parlati F, Lee SJ, Aujay M, Suzuki E, Levitsky K, Lorens JB, et al. Carfilzomib can induce tumor cell death through selective inhibition of the chymotrypsin-like activity of the proteasome. Blood. 2009;114:3439-47.

89. Kim KB, Myung J, Sin N, Crews CM. Proteasome inhibition by the natural products epoxomicin and dihydroeponemycin: Insights into specificity and potency. Bioorg Med Chem Lett. 1999;9:3335-43.

90. Wei DH, Lei BL, Tang MS, Zhan CG. Fundamental reaction pathway and free energy profile for inhibition of proteasome by epoxomicin. J Am Chem Soc. 2012;134:10436-50.

91. Neilsen PM, Pehere AD, Pishas KI, Callen DF, Abell AD. New 265 proteasome inhibitors with high selectivity for chymotrypsin-like activity and p53-dependent cytotoxicity. ACS Chem Biol. 2013;8:353-9.

92. Galko MJ, Tessier-Lavigne M. Function of an axonal chemoattractant modulated by metalloprotease activity. Science. 2000;289:1365-7.

93. Klemba M, Goldberg DE. Biological roles of proteases in parasitic protozoa. Annu Rev Plant Physiol Plant Mol Biol. 2002;71:275-305.

94. Johnsen M, Lund LR, Romer J, Almholt K, Dano K. Cancer invasion and tissue remodeling: common themes in proteolytic matrix degradation. Curr Opin Cell Biol. 1998;10:667-71.

95. Kohn EC, Liotta LA. Molecular insights into cancer invasion: strategies for prevention and intervention. Cancer Res. 1995;55:1856-62.

96. Netzel-Arnett S, Hooper JD, Szabo R, Madison EL, Quigley JP, Bugge TH, et al. Membrane anchored serine proteases: a rapidly expanding group of cell surface proteolytic enzymes with potential roles in cancer. Cancer Metastasis Rev. 2003;22:237-58.

97. Heutinck KM, ten Berge IJM, Hack CE, Hamann J, Rowshani AT. Serine proteases of the human immune system in health and disease. Molec Immunol. 2010;47:1943-55.

98. Rakashanda S, Rana F, Rafiq S, Masood A, Amin S. Role of proteases in cancer: a review. Biotechnol Mol Biol Rev. 2012;7:90-101.

99. Tani K, Ogushi F, Kido H, Kawano T, Kunori Y, Kamimura T, et al. Chymase is a potent chemoattractant for human monocytes and neutrophils. J Leukocyte Biol. 2000;67:585-9.

100. Tani K, Murphy WJ, Chertov O, Oppenheim JJ, Wang JM. The neutrophil granule protein cathepsin $\mathrm{G}$ activates murine $\mathrm{T}$ lymphocytes and upregulates antigen-specific Ig production in mice. Biochem Biophys Res Comm. 2001;282:971-6.

101. Friedl $P$, Wolf $K$. Tumour-cell invasion and migration: diversity and escape mechanisms. Nature Revs Cancer. 2003:3:362-74.

102. Nakamura K, Hongo A, Kodama J, Abarzua F, Nasu Y, Kumon H, et al. Expression of matriptase and clinical outcome of human endometrial cancer. Anticancer Res. 2009;29:1685-90.

103. Fang JD, Chou HC, Tung HH, Huang PY, Lee SL. Endogenous expression of matriptase in neural progenitor cells promotes cell migration and neuron differentiation. J Biol Chem. 2011;286:5667-79.

104. Moffitt KL, Walker B, Martin SL. Chymotrypsin-like serine proteinases are involved in the maintenance of cell viability. Biochimie. 2012;94:2582-9.

105. Oberst MD, Johnson MD, Dickson RB, Lin CY, Singh B, Stewart M, et al. Expression of the serine protease matriptase and its inhibitor HAl-1 in epithelial ovarian cancer: correlation with clinical outcome and tumor clinicopathological parameters. Clin Cancer Res. 2002;8:1101-7.

106. Hempel D, Wojtukiewicz MZ, Kozlowski L, Romatowski J, Ostrowska H Increased plasma proteasome chymotrypsin-like activity in patients with advanced solid tumors. Tumor Biol. 2011;32:753-9.

107. Chou FP, Chen YW, Zhao XF, Xu-Monette ZY, Young KH, Gartenhaus RB, et al. Imbalanced matriptase pericellular proteolysis contributes to the pathogenesis of malignant B-cell lymphomas. Amer J Pathol. 2013;183:1306-17.

108. Sulpizio S, Franceschini N, Piattelli A, Di Sebastiano P, Innocenti $P$, Selvaggi F. Cathepsins and pancreatic cancer: the 2012 update. Pancreatology. 2012;12:395-401.

109. Ostermann E, Garin-Chesa P, Heider KH, Kalat M, Lamche H, Puri C, et al. Effective immunoconjugate therapy in cancer models targeting a serine protease of tumor fibroblasts. Clin Cancer Res. 2008;14:4584-92. 
110. Lei KF, Liu BY, Zhang $X Q$, Jin $X L$, Guo Y, Ye M, et al. Development of a survival prediction model for gastric cancer using serine proteases and their inhibitors. Exp Therap Med. 2012;3:109-16.

111. Lowe FC, Isaacs JT. Biochemical methods for predicting metastatic ability of prostatic-cancer utilizing the dunning R-3327 rat prostatic adenocarcinoma system as a model. Cancer Res. 1984:44:744-52.

112. Putnam JB, Royston $D$, Chambers AF, Dunbar S, Lemmer JH, Norman $P$, et al. Evaluating the role of serine protease inhibition in the management of tumor micrometastases. Oncology. 2003;17(S10):9-30.

113. Tsai CH, Teng CH, Tu YT, Cheng TS, Wu SR, Ko CJ, et al. HAl-2 suppresses the invasive growth and metastasis of prostate cancer through regulation of matriptase. Oncogene. 2014;33:4643-52.

114. Wu SR, Cheng TS, Chen WC, Shyu HY, Ko CJ, Huang HP, et al. Matriptase is involved in ErbB-2-induced prostate cancer cell invasion. Am J Pathol. 2010;177:3145-58.

115. Yamamoto H, Iku S, Adachi Y, Imsumran A, Taniguchi H, Nosho K, et al. Association of trypsin expression with tumour progression and matrilysin expression in human colorectal cancer. J Pathol. 2003;199: 176-84.

116. Soreide K, Janssen EA, Korner H, Baak JPA. Trypsin in colorectal cancer: molecular biological mechanisms of proliferation, invasion, and metastasis. J Pathol. 2006;209:147-56.

117. Puente XS, Lopez-Otin C. A genomic analysis of rat proteases and protease inhibitors. Genome Res. 2004;14:609-22.

118. Howes N, Greenhalf W, Stocken DD, Neoptolemos JP. Cationic trypsinogen mutations and pancreatitis. Gastroenterol Clin N Am. 2004; 33:767-70.

119. Song Y, Wang P, Zhao W, Yao Y, Liu X, Ma J, et al. MiR-18a regulates the proliferation, migration and invasion of human glioblastoma cell by targeting neogenin. Exp Cell Res. 2014;324:54-64.

120. Coissieux M-M, Tomsic J, Castets M, Hampel H, Tuupanen S, Andrieu N, et al. Variants in the Netrin-1 Receptor UNC5C prevent apoptosis and increase risk of familial colorectal cancer. Gastroenterology. 2011;141:2039-46.

121. Ishibe N, Freedman AN. Understanding the interaction between environmental exposures and molecular events in colorectal carcinogenesis. Cancer Invest. 2001;19:524-39.

122. Wu S, Powers S, Zhu W, Hannun YA. Substantial contribution of extrinsic risk factors to cancer development. Nature. 2015:529:43-7.

123. Dejea CM, Wick EC, Hechenbleikner EM, White JR, Welch JLM, Rossetti BJ, et al. Microbiota organization is a distinct feature of proximal colorectal cancers. Proc Natl Acad Sci U S A. 2014;111:18321-6.

124. Lorkowski G. Gastrointestinal absorption and biological activities of serine and cysteine proteases of animal and plant origin: review on absorption of serine and cysteine proteases. Int J Physiol Pathophysiol Pharmacol. 2012;4:10-27.

125. Goswami R, Tandon RK, Dudha A, Kochupillai N. Prevalence and significance of steatorrhea in patients with active Graves' disease. Am J Gastroenterol. 1998:93:1122-5

126. Walkowiak J, Madry E, Lisowska A, Szaflarska-Poplawska A, Grzymislawski M, Stankowiak-Kulpa $\mathrm{H}$, et al. Adaptive changes of pancreatic protease secretion to a short-term vegan diet: influence of reduced intake and modification of protein. Brit J Nutr. 2012;107:272-6.

127. Haverback BJ, Dyce BY, Gutentag PJ, Montgomery DW. Measurement of trypsin and chymotrypsin in stool. Gastroenterology. 1963;44:588-97.

128. Schneider R, Dtirr HK, Bode JC. Diagnostische Wertigkeit der Bestimmung von Chymotrypsin im Stuhl fur die Erfassung einer exokrinen Pankreasinsuffizienz. Dtsch Med Wochenschr. 1974;99:1449-54.

129. Henker J, Hackbarth S, Sprossig C. Fecal chymotrypsin concentration in childhood - normal values, sensitivity, specificity. Helv Paed Acta. 1989;43:397-404

130. Sziegoleit A, Krause E, Klor HU, Kanacher L, Linder D. Elastase-1 and chymotrypsin-B in pancreatic-juice and feces. Clin Biochem. 1989;22:85-9.

131. Carroccio A, lacono G, Lerro P, Cavataio F, Malorgio E, Soresi M, et al. Role of pancreatic impairment in growth recovery during gluten-free diet in childhood celiac disease. Gastroenterology. 1997;112:1839-44

132. Orlich M, Singh PN, Sabaté J, Fan J, Sveen L, Bennett $H$, et al. Vegetarian dietary patterns and the risk of colorectal cancers. JAMA Intern Med. 2015:175:767-76.

133. Suzuki M, Taguchi S, Yamada S, Kojima S, Miura Kl, Momose H. A novel member of the subtilisin-like protease family from Streptomyces albogriseolus. J Bacteriol. 1997;179:430-8.
134. Wanyiri JW, Techasintana P, O'Connor RM, Blackman MJ, Kim K, Ward HD. Role of CpSUB1, a subtilisin-like protease, in Cryptosporidium parvum Infection In Vitro. Eukaryotic Cell. 2009;8:470-7.

135. Lanigan-Gerdes S, Dooley AN, Faull KF, Lazazzera BA. Identification of subtilisin, Epr and Vpr as enzymes that produce CSF, an extracellular signalling peptide of Bacillus subtilis. Molec Microbiol. 2007;65:1321-33.

136. Reichard U, Buttner S, Eiffert H, Staib F, Ruchel R. Purification and characterization of an extracellular serine proteinase from Aspergillus-Fumigatus and its detection in tissue. J Med Microbiol. 1990;33:243-51.

137. MacGregor DG, Mallon AP, Harvey AL, Young L, Nimmo HG, Stone TW. Group S8A serine proteases, including a novel enzyme cadeprin, induce long-lasting, metabotropic glutamate receptor-dependent, synaptic depression in rat hippocampal slices. Europ J Neurosci. 2007;26:1870-80

138. Shi L, Li R, Liao S, Bai L, Lu Q, Chen B. Prb1, a subtilisin-like protease, is required for virulence and phenotypical traits in the chestnut blight fungus. FEMS Microbiol Lett. 2014;359:26-33.

139. Landowski CP, Huuskonen A, Wahl R, Westerholm-Parvinen A, Kanerva A Hanninen $A-L$, et al. Enabling low cost biopharmaceuticals: a systematic approach to delete proteases from a well-known protein production host Trichoderma reesei. PLoS One. 2015;10:ARe0134723.

140. Tam NMK, Uyen NQ, Hong HA, Duc LH, Hoa TT, Serra CH, et al. The intestinal life cycle of Bacillus subtilis and close relatives. J Bacteriol. 2006;188:2692e2700.

141. Fakhry S, Sorrentini I, Ricca E, De Felice M, Baccigalupi L. Characterization of spore forming Bacilli isolated from the human gastrointestinal tract. J Appl Microbiol. 2008;105:2178-86.

142. Hoa TT, Duc LH, Isticato R, Baccigalupi L, Ricca E, Van PH, et al. Fate and dissemination of Bacillus subtilis spores in a murine model. Appl Environ Microbiol. 2001:67:3819-23.

143. Casula G, Cutting SM. Bacillus probiotics: spore germination in the gastrointestinal tract. App Environ Microbiol. 2002;68:2344e2352.

144. Gupta R, Beg QK, Lorenz P. Bacterial alkaline proteases: molecular approaches and industrial applications. Appl Microbiol Biotechnol. 2002:59:15-32.

145. Duc LH, Hong HA, Barbosa TM, Henriques AO, Cutting SM. Characterization of Bacillus probiotics available for human use. Appl Environ Microbiol. 2004;70:2161e2171.

146. Hoa NT, Baccigalupi L, Huxham A, Smertenko A, Van PH, Ammendola S, et al. Characterization of Bacillus species used for oral bacteriotherapy and bacterioprophylaxis of gastrointestinal disorders. Appl Env Microbiol. 2000;66:241e5247.

147. Hong HA, Duc LH, Cutting SM. The use of bacterial spore formers as probiotics. FEMS Microbiol Rev. 2005;29:813e835.

148. HERA. Human and Environmental Risk Assessment on ingredients of household cleaning products: subtilisins (protease). 2007: http://www.heraproject.com/files/ 22-F-07_PROTEASE_HERA_Final\%20Edition\%20(unsecured\%20-\%20PDFA-1b). pdf. Accessed 23 Sept 2016

149. Marouani-Gadri N, Augier G, Carpentier B. Characterization of bacterial strains isolated from a beef-processing plant following cleaning and disinfection - influence of isolated strains on biofilm formation by Sakai and EDL933 E.coli O157:H7. Intern J Food Microbiol. 2009:133:62-7.

150. Gregova G, Venglovsky J, Vargova M, Ondrasuovic M, Ondrasovicova O, Lakticova $\mathrm{K}$, et al. The biological danger associated with the creation of bioaerosols in farm buildings used for animal housing. Slovak Vet J. 2009:34:154-6.

151. US Household Products Database (https://householdproducts.n/m.nih.gov/ cgi-bin/household/brands?tbl=chem\&id=1699). Accessed 23 Sept 2016.

152. Losso JN. The biochemical and functional food properties of the Bowman-Birk inhibitor. Crit Revs Food Sci Nutr. 2008:48:94-118.

153. Tedeschi F, Di Maro A, Facchiano A, Costantini S, Chambery A, Bruni N, et al. Wheat subtilisin/chymotrypsin inhibitor (WSCI) as a scaffold for novel serine protease inhibitors with a given specificity. Molec Biosystems. 2012:8:3335-43.

154. Parfenov IA, Revina TA, Gerasimova NG, Kladnitskaya GV, Valueva TA. Heterologous expression, purification, and properties of a chymotrypsin inhibitor isolated from potatoes. Appl Biochem Microbiol. 2013:49:28-33.

155. Joanitti GA, Azevedo RB, Freitas SM. Apoptosis and lysosome membrane permeabilization induction on breast cancer cells by an anticarcinogenic Bowman-Birk protease inhibitor from Vigna unguiculata seeds. Cancer Lett. 2010:293:73-81.

156. El Rayes R, Catena R, Lee S, Stawowczyk M, Joshi N, Fischbach C, et al. Lung inflammation promotes metastasis through neutrophil protease-mediated degradation of Tsp-1. Proc Natl Acad Sci U S A. 2015;112:16000-5. 
157. Ware JH, Wan XS, Rubin H, Schechter NM, Kennedy AR. Soybean Bowman-Birk protease inhibitor is a highly effective inhibitor of human mast cell chymase. Arch Biochem Biophys. 1997;344:133-8.

158. Clemente A, Gee JM, Johnson IT, Mackenzie DA, Domoney C. Pea (Pisum sativum $L$.) protease inhibitors from the Bowman-Birk class influence the growth of human colorectal adenocarcinoma HT29 cells in vitro. J Agric Food Chem. 2005;53:8979-86.

159. Kennedy AR, Wan XS. Effects of the Bowman-Birk inhibitor on growth, invasion, and clonogenic survival of human prostate epithelial cells and prostate cancer cells. Prostate. 2002;50:125-33.

160. Clemente A, Moreno FJ, Marin-Manzano MC, Jimenez E, Domoney C. The cytotoxic effect of Bowman-Birk isoinhibitors, IBB1 and IBBD2, from soybean (Glycine max) on HT29 human colorectal cancer cells is related to their intrinsic ability to inhibit serine proteases. Molec Nutr Food Res. 2010;54:396-405.

161. Clemente A, Marin-Manzano MC, Jimenez E, Arques MC, Domoney C. The anti-proliferative effect of TI1B, a major Bowman-Birk iso-inhibitor from pea (Pisum sativum L.), on HT29 colon cancer cells is mediated through protease inhibition. Brit J Nutr. 2012;108:S135-44.

162. Kennedy AR, Billings PC, Wan XS, Newberne PM. Effects of Bowman-Birk inhibitor on rat colon carcinogenesis. Nutr Cancer. 2002;43:174-86.

163. Meyskens FL. Development of Bowman-Birk inhibitor for chemoprevention of oral head and neck cancer. Ann N Y Acad Sci. 2001:952:116-23.

164. Wan XS, Lu LJW, Anderson KE, Ware JH, Kennedy AR. Urinary excretion of Bowman-Birk inhibitor in humans after soy consumption as determined by a monoclonal antibody-based immunoassay. Cancer Epid Biomark Prev. 2000;9:741-7.

165. Wan XS, Serota DG, Ware JH, Crowell JA, Kennedy AR. Detection of Bowman-Birk inhibitor and anti-Bowman-Birk inhibitor antibodies in sera of humans and animals treated with Bowman-Birk inhibitor concentrate. Nutr Cancer. 2002;43:167-73.

166. Clemente A, Sonnante G, Domoney C. Bowman-Birk inhibitors from legumes and human gastrointestinal health: current status and perspectives. Curr Prot Pept Sci. 2011:12:358-73.

\section{Submit your next manuscript to BioMed Central and we will help you at every step:}

- We accept pre-submission inquiries

- Our selector tool helps you to find the most relevant journal

- We provide round the clock customer support

- Convenient online submission

- Thorough peer review

- Inclusion in PubMed and all major indexing services

- Maximum visibility for your research

Submit your manuscript at www.biomedcentral.com/submit

) Biomed Central 